\title{
Contribution to the Ground Water Hydrology of the Quaternary Aquifer in West Ismailia Area, Egypt
}

\author{
Salah Abdelwahab El-Sayed \\ Siting and Environmental Department, Egyptian Nuclear and Radiological Regulatory Authority, ENRRA, Cairo, Egypt \\ Email: saelwahab132@yahoo.com
}

How to cite this paper: El-Sayed, S.A. (2018) Contribution to the Ground Water Hydrology of the Quaternary Aquifer in West Ismailia Area, Egypt. Journal of Geoscience and Environment Protection, 6, 134-158.

https://doi.org/10.4236/gep.2018.67010

Received: June 30, 2018

Accepted: July 28, 2018

Published: July 31, 2018

Copyright $\odot 2018$ by author and Scientific Research Publishing Inc. This work is licensed under the Creative Commons Attribution International License (CC BY 4.0).

http://creativecommons.org/licenses/by/4.0/

(c) (i) Open Access

\begin{abstract}
Hydrologic conditions of the ground water of the Quaternary aquifer in west Ismailia area, Egypt, were characterized based on new hydrologic data collected in 2017. The Quaternary aquifer consists of alluvial deposits. The grain size distribution results indicate that the major part of the aquifer deposits is formed of medium to coarse grained sand with medium uniformity coefficients ranging between 2.5 and 10 . They also reflect the heterogeneity, anisotropy and high productivity of the aquifer. The estimated aquifer parameters range from $29 \%$ to $41 \%$ for total porosity, from $18.71 \mathrm{~m} /$ day to $63.95 \mathrm{~m} /$ day for horizontal hydraulic conductivity, from $8.94 \mathrm{~m} /$ day to $61.6 \mathrm{~m} /$ day for vertical hydraulic conductivity, from 1.01 to 4.27 for anisotropy and from 1870 $\mathrm{m}^{2} /$ day to $6549 \mathrm{~m}^{2} /$ day for transmissivity. The ground water flows mainly from the north and northeast recharge sources (Ismailia and El Manaief canals) and from the south recharge area (Miocene aquifer), with an average hydraulic gradient of 0.00438 . The recharge rate to the aquifer (from the southern area) and the Darcy's velocity of ground water are estimated to be $447 \times$ $10^{6} \mathrm{~m}^{3} /$ year and $0.203 \mathrm{~m} /$ day (on average), respectively. A great change in the hydrologic setting of the aquifer is occurred during the period of 1992-2017, where the groundwater flow has changed during that period. The aquifer contains fresh to saline water. An oxidizing (alkaline) environment is reported for the aquifer, as revealed from the relationship between the redox potential $(185-836 \mathrm{mV})$ and $\mathrm{pH}(5.2-7.5$ standard units). This indicated the capability of ground water to dissolve heavy metals associated to rock-forming minerals. A wide variation in the concentrations of total dissolved solids (320 - 7385 $\mathrm{mg} / \mathrm{l})$ and dissolved oxygen $(2.13-8.4 \mathrm{mg} / \mathrm{l})$ in the Quaternary aquifer is observed, reflecting the local variation of the environmental and geologic conditions and indicating the influence of different recharge sources.
\end{abstract}




\section{Keywords}

Ground Water Flow and Recharge, Hydraulic Parameters, Aqueous

Environment, Quaternary Aquifer, West Ismailia Area, Egypt

\section{Introduction}

Ismailia is one of the most important Egyptian's governorates where it represents the eastern gate to Asia and some Arab countries. The western part of Ismailia (the study area) is a desert land, except for the northern narrow green belt overlooking Ismailia Canal. Great efforts were made by the Egyptian governments and private sectors since the early 1960s to reclaim this desert land. Several agricultural and industrial projects have been accomplished, aiming to help overcome the problems of the high increase in population, unemployment and food deficiency in Egypt. The agricultural and industrial activities are expected to increase during the next years, and consequently, the need to ground water resources will increase.

The Quaternary aquifer in west Ismailia area is the main resource for ground water supply. Previous investigations, such as [1]-[7] indicated that the quality of the ground water in many parts of the aquifer is influenced by the executed reclamation activities, intensive pumping, and natural hydrogeochemical processes. Moreover, the ground water in the western part of the study area is the more vulnerable to contaminations with heavy metals due to the recharge by infiltration from liquid industrial and domestic wastes of the oxidation ponds found in the tenth of Ramadan City.

As the Quaternary aquifer represents the main aquifer in the studied area, a hydrologic re-evaluation for the aquifer should be made periodically. Rational management of the aquifer is necessary to meet increased agricultural, industrial and domestic demands. It requires good understanding of the various components of the aquifer hydrologic system.

Therefore, this paper presents more detailed knowledge about the ground water hydrology of the Quaternary aquifer in the study area. It describes the occurrence, flow and hydraulic gradient, recharge and discharge of ground water as well as the interaction with surface water streams. It presents an estimation of the hydraulic parameters (porosity, horizontal and vertical hydraulic conductivities, anisotropy and transmissivity) and sheds light on the characteristics of the aqueous environment of the aquifer. Findings of this work are very important to ascertain the best methods of the aquifer development. They are of great importance in case of conducting solute transport models and water budgets in the area.

\section{Materials and Methods}

\subsection{Physiographic and Geologic Setting}

The study area, west of Ismailia, is situated at the northern part of the Eastern 
Desert of Egypt, between latitudes $30.3^{\circ}$ and $30.57^{\circ} \mathrm{N}$ and longitudes $31.6^{\circ}$ and $32.3^{\circ} \mathrm{E}$ (Figure 1). It occupies an area of about $1150 \mathrm{~km}^{2}$. The area has a desert climate with hot summers and mild winters. The average annual temperature and precipitation are $21.3^{\circ} \mathrm{C}$ and $26 \mathrm{~mm}$ [8]. The evaporation rate is high ranging from $6 \mathrm{~mm} /$ day to $12 \mathrm{~mm} /$ day [9]. The area is bounded from the north by Ismailia Canal, from east by the Suez Canal and Bitter Lakes, from the west by the $10^{\text {th }}$ of Ramadan City and from the south by Cairo-Ismailia Desert Road.

Topographically, the area slopes northwards with altitudes ranging from 250 $\mathrm{m}$ above mean sea level (amsl) in the southern part of the area to $9 \mathrm{~m}$ (amsl) in the northern part. Its surface is subdivided into three geomorphologic units, the Belbies-El Tell El Kabeir-El Salhyia plains, Wadi El Tumilat depression, and Ankabia-Aweibid structural plain (Figure 2) [1] [10] [11]. A brief physiographic overview is presented hereinafter.

Belbies-El Tell El Kabeir-El Salhyia plains comprise the flats lying to the south of Ismailia Canal and extend to the Suez Canal. The surface is mainly covered by typical sands and gravels of Pleistocene age. Wadi El Tumilat depression is an E-W elongated depression extending parallel to Ismailia Canal with an average width and length reaching $7 \mathrm{~km}$ and $52 \mathrm{~km}$, respectively. Its surface is covered by the Quaternary stabilized sand dunes. Ankabia-Aweibid structural plain is represented by a series of an E-W elongated structurally controlled ridges. The surface is covered by a variety of sediments (sand, gravel, sandstone and basaltic extrusions) belonging to the Tertiary age. The forelands of the structural ridges are dissected by a number of shallow and deep drainage lines that terminate northwards and eastwards.

Geologically, west Ismailia area is underlain by sedimentary rocks of Quaternary and Tertiary age (Figure 3). The Quaternary sediments underlie the northern and central parts of the study area. They are represented by the Holocene-aeolian sand and silt ( $\sim 0 \mathrm{~m}$ thick) and the Pleistocene-sand and gravel with clay lenses ( $352 \mathrm{~m}$ thick). They overlie unconformably the Miocene deposits in the north and south of Wadi El-Tumilat [9].

The Tertiary sediments underlie the southern parts of the study area (south of the latitude $21^{\circ} 00^{\prime} \mathrm{N}$ ). The surface and subsurface stratigraphic succession of the Tertiary rock is investigated by many authors, such as [1] [9] [12] [13] [14]. The Pliocene rocks are represented by Hagif Formation formed of shallow marine limestone and marl ( $190 \mathrm{~m}$ thick). The Miocene rocks are represented by $\mathrm{Ha}-$ gul Formation ( $\sim 220 \mathrm{~m}$ thick) that is mostly composed of alternations of sandy limestone and clay layers. Such rocks are well exposed at the Tenth of Ramadan City and flat-lying areas in the southern mountain places. The Oligocene rocks are represented by Gebel Ahmer Formation ( $260 \mathrm{~m}$ thick) formed of colored sands, quartz and gravels that are capped, in some places, by basaltic extrusion. The Eocene Rocks are represented by Maadi Formation and Mokatam Group, which are made of shallow marine shale and limestone intercalated with sands and clay layers $(\sim 430 \mathrm{~m}$ thick). 
From the structure point of view, west Ismailia area falls within the unstable shelf dominating the northern part of Egypt [15]. The regional geologic structure

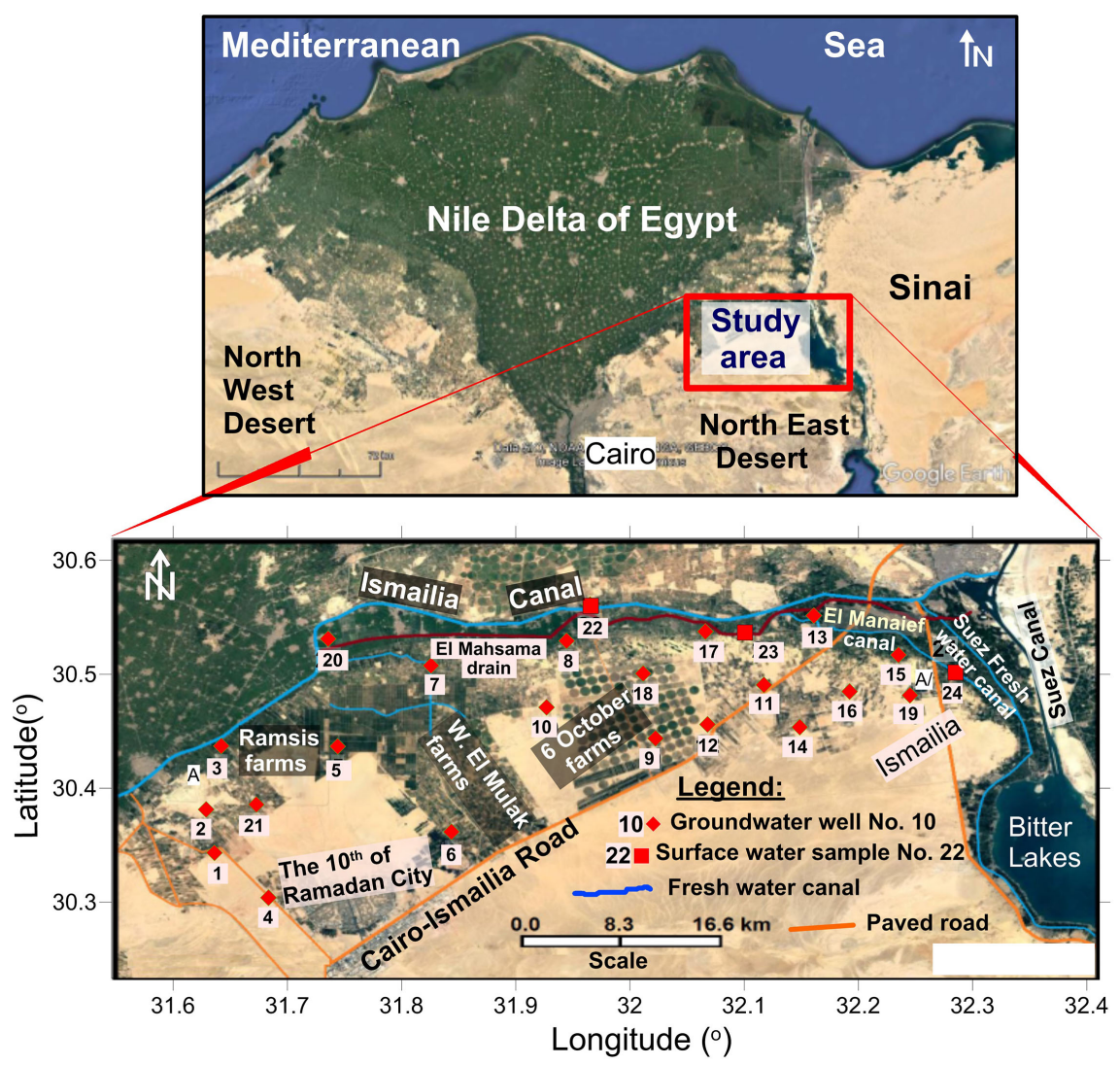

Figure 1. Location map of West Ismailia area, Egypt, showing the sampling points (production wells and main surface water bodies), source of maps is Google Earth, map data, 2017.

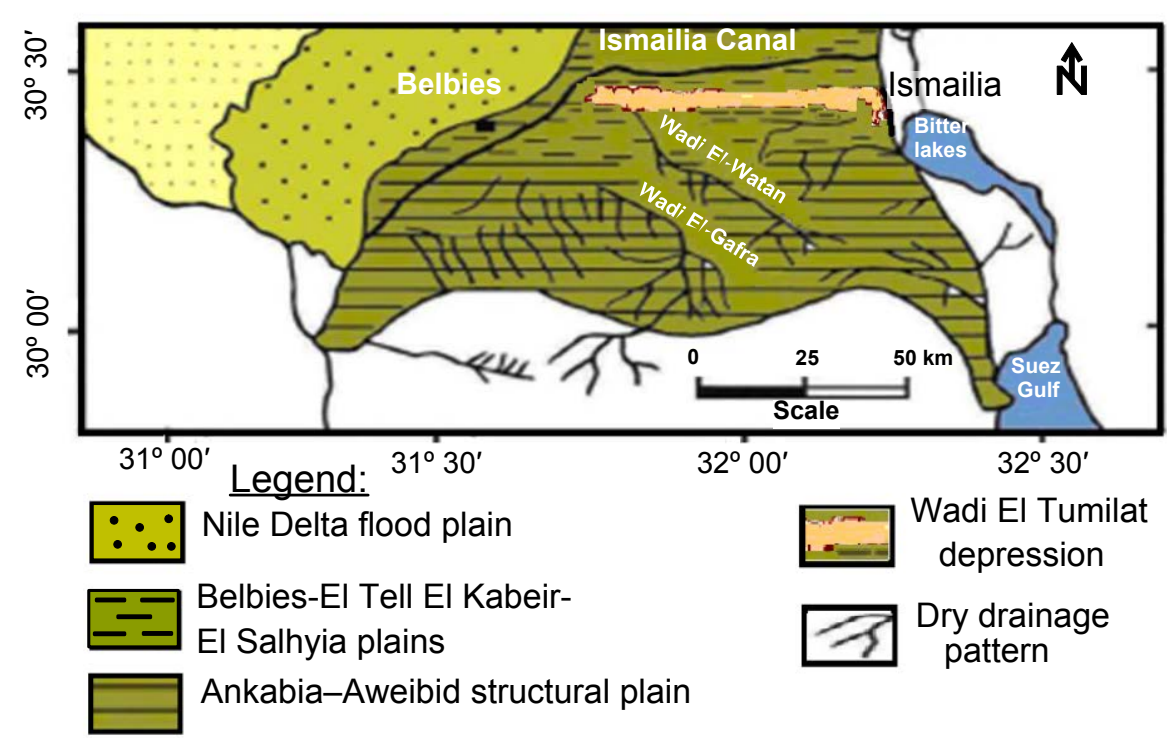

Figure 2. Geomorphologic map of west Ismailia area, Egypt (slightly modified after [11]). 


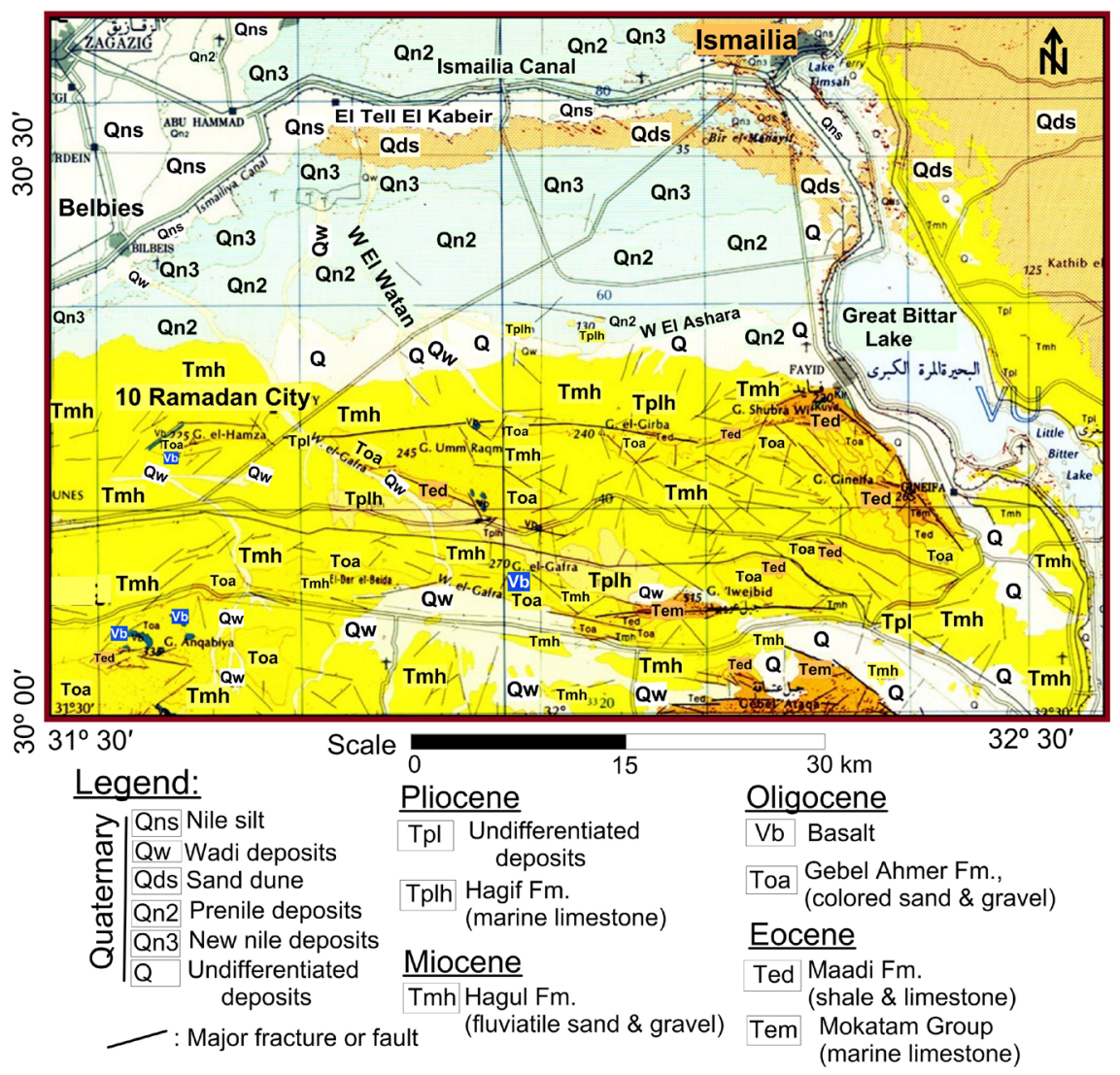

Figure 3. Geologic map of west Ismailia area, Egypt, after [14].

is a low northward dipping homocline, which controls the thicknesses of some aquifers. For instance, the thickness of the Quaternary aquifer increases northwards by the rate $3 \mathrm{~m} / \mathrm{km}$ [16]. The detected faults in the area are of normal type striking in an E-W, NW-SE and NE-SW directions. Faulting has a pronounced effect on the terrains and hydrogeology of the area.

\subsection{Ground Water Measurements}

Field campaign was achieved in west Ismailia area in January 2017 with the aim of collecting hydrologic data. Information about depths, diameters, and heads of 21 wells tapping the Quaternary aquifer were collected. The water levels inside these wells were measured, where possible, using a water level meter; model kurt, MIGGGE, Gm.b. H, 69 Heidelberg 1. The coordinates and elevations with respect to mean sea level of all water points were determined by a global positioning system device, eTrex, Personal Navigator.

Field measurements were made for ground water phsico-chemical parameters using Manta 2, Water-Quality Multiprobe, Model Sub 3, USA. They included ground water temperature, $\mathrm{pH}$, total dissolved solid (TDS), specific conductance (SPC), dissolved oxygen (DO) and oxidation reduction potential (ORP). The same parameters were conducted also for three main surface water bodies (Ismailia Canal, El-Mahsama drain and El Manaief canal) in the area. The meas- 
ured field ORP values for ground water and surface water samples were converted into redox potential (Eh) by adding the known half-cell potential of the reference electrode [17]:

$$
\mathrm{Eh}_{\text {sample }}=\mathrm{ORP}_{\text {sample }}+\text { half-cell potential of reference electrode }
$$

For the used Manta 2 device, the actual ORP sensor is the $1 \mathrm{~mm}$ silver and the reference electrolyte is the $\mathrm{KCl}$ saturated with silver chloride. According to the temperature degrees measured for the water samples, the used half-cell potential values are $199 \mathrm{mV}\left(\right.$ at $\left.25^{\circ} \mathrm{C}\right)$ and $194 \mathrm{mV}$ at $\left(25^{\circ} \mathrm{C}\right)$ [17].

\subsection{Grain Size Analysis for Estimating Aquifer Parameters}

Drill cuttings (41 samples) representing different horizons of the Quaternary aquifer materials were obtained and analyzed for grain size using an analytical sieve shaker, model; Retch, D-42759, HAAN-Germany. The analyses were conducted at the Hydrogeological Lab., Egyptian Nuclear and Radiological Regulatory Authority. The aquifer material samples were tested using a series of sorted sieves ranging from $4 \mathrm{~mm}$ to $0.045 \mathrm{~mm}$. An example showing the method of calculation of grain size parameters is presented in Table 1. The test results, comprising the grain size (in $\mathrm{mm}$ ) and the percentage passing (\%), were plotted on a semi-logarithmic graph to obtain the grain-size distribution curve for the sample as shown in Figure 4. From the distribution curve, the diameters of soil particles at $10 \%$ and $60 \%$ cumulative weight were determined, and then the coefficient of grain uniformity $(u)$ was calculated.

The aquifer parameters were estimated based on the obtained grain size distribution data. The porosity of the aquifer was determined by applying the common equation presented by [18]. The hydraulic conductivity of each horizon (depth interval) was estimated using Kozeny equation [19] in [20]. The horizontal and vertical hydraulic conductivities $\left(K_{h}\right.$ and $\left.K_{V}\right)$ of the aquifer were estimated by applying the equations given by [21], using the obtained Kozeny hydraulic conductivities and the thickness of the tested aquifer horizons. Anisotropy of the aquifer hydraulic conductivity was determined from the relation $\left(K_{h l} / K_{v}\right)$ given by [22]. The transmissivity of the aquifer was determined from the obtained vertical hydraulic conductivity and average aquifer thickness. Finally, recharge rate to the aquifer and specific discharge was determined using Darcy equation [23].

\section{Results and Discussion}

\subsection{The Quaternary Water Bearing Sediments}

The Quaternary aquifer in the study area consists of unconsolidated fluviatile sediments (sands and gravels interbedded with clay lenses) (Figure 5). The lithofacies of the aquifer materials changes laterally and vertically. The content of gravels increases at the base of the aquifer. Intercalations of clay and calcareous materials are found to increase in the northeastern part of the study area. West of the longitude $32.1^{\circ} \mathrm{E}$, the area (about $2-7 \mathrm{~km}$ in width) overlooking 


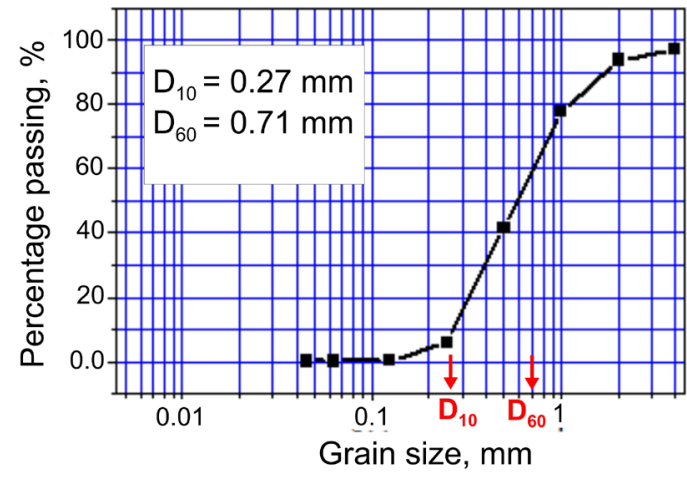

Figure 4. Grain size distribution curve, well No. 2, depth interval from $10 \mathrm{~m}$ to $18 \mathrm{~m}$ (below mean sea level).

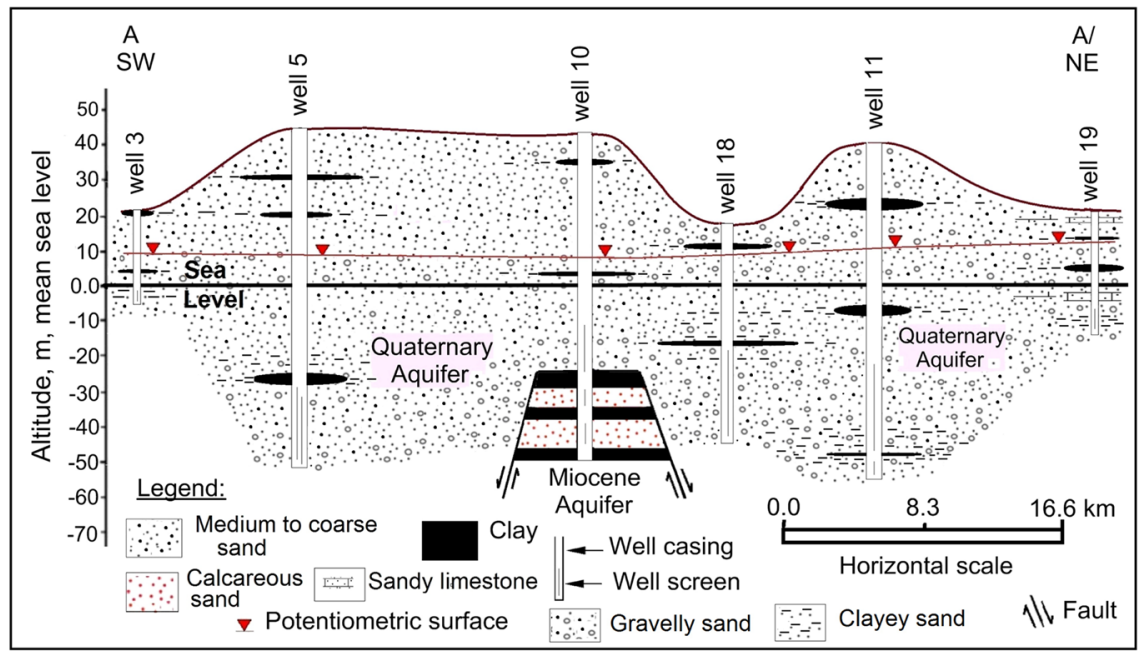

Figure 5. Hydrogeological cross section A-A/cutting the study area in an NE-SW direction (direction of the cross section is shown in Figure 1).

Table 1. The results of particle size distribution test, well No. 2, depth interval from -10 $\mathrm{m}$ to $-18 \mathrm{~m}$ below mean sea level.

\begin{tabular}{ccccc}
\hline $\begin{array}{c}\text { Mesh opening, } \\
\mathrm{mm}\end{array}$ & $\begin{array}{c}\text { Weight } \\
\text { retained, gm }\end{array}$ & $\begin{array}{c}\text { Cumulative weight } \\
\text { retained, gm }\end{array}$ & $\begin{array}{c}\text { Cumative weight } \\
\text { passing, gm }\end{array}$ & $\begin{array}{c}\text { Percentage } \\
\text { passing, \% }\end{array}$ \\
\hline 4 & 12.4 & 13.4 & 458.43 & 97.1 \\
2 & 16.3 & 28.7 & 442.6 & 93.8 \\
1 & 76.23 & 104.93 & 366.9 & 77.8 \\
0.5 & 170 & 274.93 & 196.9 & 41.7 \\
0.25 & 168.4 & 443.33 & 28.5 & 6.04 \\
0.125 & 27.08 & 470.41 & 1.42 & 0.30 \\
0.063 & 1.2 & 471.61 & 0.22 & 0.05 \\
0.045 & 0.06 & 471.67 & 0.16 & 0.03 \\
pan & 0.16 & 471.83 & 0.00 & 0.00 \\
Total & 471.83 & - & - & - \\
\hline
\end{tabular}


Ismailia Canal is overlain by the semi permeable Holocene silty and sandy clay layer acting as an aquiclude, rendering the ground water under semi-confining conditions. In the rest of the area, the aquifer is overlain by sands and gravels, which render the ground water under un-confining conditions. The Quaternary aquifer unconformably overlies the Miocene aquifer formed essentially of alternation of calcareous sands and clays layers. The thickness of the aquifer increases northwards, averaging about $100 \mathrm{~m}$ [13] [24].

\subsection{Aquifer Parameters}

The Quaternary aquifer hydraulic parameters are estimated based on the analysis of the grain size distribution data of some continuous aquifer horizons (Table 2 ). They include the porosity $(\Phi)$, hydraulic conductivity obtained using Kozeny formula $\left(K_{\text {kozeny }}\right)$, horizontal and vertical aquifer hydraulic conductivities ( $K_{h}$ and $\left.K_{v}\right)$, anisotropy $\left(K_{h} / K_{v}\right)$, and transmissivity. Also included are the lithic descriptions of each tested horizon. The lithology of the aquifer is dominated by medium to coarse grained sand with few amounts of clay and gravel fractions.

\subsubsection{Total Porosity}

The total porosity $(\Phi)$ is the void space of the unconsolidated sedimentary materials and has a direct relation with the amount of water that can be stored in an aquifer. The $(\Phi)$ of the Quaternary aquifer is estimated by applying the following equation of [18]:

$$
\begin{gathered}
\Phi=0.255\left(1+0.83^{u}\right) \% \\
u=D_{60} / D_{10}
\end{gathered}
$$

where the $D_{10}$ and $D_{60}$ are the grain sizes parameters corresponding to $10 \%$ and $60 \%$, respectively, by weight passing $(\mathrm{mm})$.

The results of grain size analysis (Table 2 ) show that all samples have medium uniformity coefficients values $(2.5<u<10)$, which indicates that the samples are of medium uniform grain deposits. The porosity values of the studied aquifer horizons (from $+10 \mathrm{~m}, \mathrm{msl}$, to $-50 \mathrm{~m}, \mathrm{msl}$ ) range from $29 \%$ to $41 \%$. These values reflect the nature of aquifer materials, which are dominated by sand fractions. Figure 6 shows the distribution of the average porosity in the Quaternary aquifer. The average porosity values (from $36 \%$ to $40.6 \%$ ) are generally high and increase northwestwards. The increase in the porosity values could be attributed to the dominance fine grained sand and clay content. The high porosity values refer to the high storage capacity of the Quaternary aquifer.

\subsubsection{Hydraulic Conductivity}

The hydraulic conductivity $(K)$ expresses the ease with which the ground water porous media. The $K$ parameter of geologic units is essential for better ground water development, management and conservation. Knowing $(K)$ is also required for modeling the movement of water in unsaturated and saturated zones and transportation of water soluble contaminants [25] [26]. 
Table 2. Porosity, hydraulic conductivity and anisotropy estimated for the Quaternary aquifer from grain size distribution data.

\begin{tabular}{|c|c|c|c|c|c|c|c|c|c|c|c|c|}
\hline $\begin{array}{l}\text { Well } \\
\text { No. }\end{array}$ & Aqui & $\begin{array}{l}\text { horizon, } \\
\text { sl) }\end{array}$ & $\begin{array}{c}\text { Lithic } \\
\text { description }\end{array}$ & $\begin{array}{c}D_{10} \\
(\mathrm{~mm})\end{array}$ & $\begin{array}{c}D_{60} \\
(\mathrm{~mm})\end{array}$ & $u$ & $\Phi$ & $\begin{array}{c}K, \\
\mathrm{~m} / \mathrm{d}[19]\end{array}$ & $\begin{array}{c}K_{h} \\
(\mathrm{~m} / \mathrm{d})\end{array}$ & $\begin{array}{c}K_{V} \\
(\mathrm{~m} / \mathrm{d})\end{array}$ & $\begin{array}{l}\text { Anisotropy } \\
\left(K_{h} / K_{v}\right)\end{array}$ & $\begin{array}{c}T \\
(\mathrm{~m} / \mathrm{d})\end{array}$ \\
\hline \multirow{3}{*}{2} & -10 & -18 & ${ }^{\star}$ Sd, m. to v. c., with $3 \%$ gvl. & 0.27 & 0.71 & 2.73 & 0.41 & 77.94 & \multirow{3}{*}{58.47} & \multirow{3}{*}{45.86} & \multirow{3}{*}{1.27} & \multirow{3}{*}{6549} \\
\hline & -18 & -32 & Sd, m. to c., with $5 \%$ gvl. & 0.21 & 0.91 & 4.33 & 0.37 & 30.39 & & & & \\
\hline & -32 & -40 & Sd, m-c, with $8 \%$ gvl. & 0.32 & 1.14 & 3.56 & 0.39 & 88.14 & & & & \\
\hline \multirow{3}{*}{3} & 10 & 5 & Sd, f. to c. & 0.25 & 0.67 & 2.68 & 0.41 & 66.82 & \multirow{3}{*}{37.74} & \multirow{3}{*}{8.94} & \multirow{3}{*}{4.22} & \multirow{3}{*}{3673} \\
\hline & 5 & 0.0 & Clayey sand. & 0.10 & 0.99 & 9.9 & 0.29 & 2.61 & & & & \\
\hline & 0.0 & -10 & Sd, m. to c., with $5 \%$ gvl. & 0.23 & 0.82 & 3.56 & 0.38 & 40.77 & & & & \\
\hline \multirow{4}{*}{5} & -10 & -20 & Sd, m. to c. & 0.30 & 1.12 & 3.73 & 0.382 & 70.93 & \multirow{4}{*}{59.93} & \multirow{4}{*}{14.03} & \multirow{4}{*}{4.27} & \multirow{4}{*}{5993} \\
\hline & -20 & -30 & Clayey sand. & 0.11 & 0.83 & 7.54 & 0.31 & 4.09 & & & & \\
\hline & -30 & -40 & Sd, m. to c., with $5 \%$ gvl. & 0.25 & 0.78 & 3.12 & 0.397 & 58.1 & & & & \\
\hline & -40 & -50 & Sd, m. to c., with $8 \%$ gvl. & 0.35 & 1.17 & 3.34 & 0.391 & 106.6 & & & & \\
\hline \multirow{3}{*}{6} & -10 & -20 & Sd, m. to v. c. with $6 \%$ gvl. & 0.26 & 0.68 & 2.61 & 0.41 & 72.27 & \multirow{3}{*}{56.3} & \multirow{3}{*}{54.31} & \multirow{3}{*}{1.04} & \multirow{3}{*}{5634} \\
\hline & -20 & -30 & Sd, m. to c., with $8 \%$ gvl. & 0.25 & 0.99 & 3.96 & 0.377 & 46.59 & & & & \\
\hline & -30 & -40 & Sd, m. to c., with $10 \%$ gvl. & 0.27 & 1.14 & 4.22 & 0.37 & 50.15 & & & & \\
\hline \multirow{3}{*}{7} & 0.0 & -10 & Sd, m. to c. with $5 \%$ gvl. & 0.24 & 0.65 & 2.71 & 0.41 & 61.58 & & & & \\
\hline & -10 & -20 & Sd, f. to c. with $8 \%$ gvl. & 0.22 & 0.63 & 2.86 & 0.40 & 46.46 & 63.95 & 60.37 & 1.06 & 6395 \\
\hline & -20 & -30 & Sd, m. to c. with $12 \%$ gvl. & 0.28 & 0.76 & 2.71 & 0.41 & 83.82 & & & & \\
\hline & 0.0 & -10 & Sd, m. to c., with $7 \%$ gvl. & 0.27 & 0.83 & 3.07 & 0.40 & 69.98 & & & & \\
\hline 10 & -10 & -20 & Sd, f. to c. with $5 \%$ gvl. & 0.23 & 0.85 & 3.7 & 0.38 & 40.77 & 54.49 & 51.40 & 1.06 & 5390 \\
\hline & -20 & -25 & Sd, m. with $8 \%$ gvl. & 0.36 & 1.21 & 3.36 & 0.39 & 50.96 & & & & \\
\hline & -20 & -30 & Sd, f. to c. & 0.27 & 0.71 & 2.63 & 0.41 & 77.94 & & & & \\
\hline 11 & -30 & -40 & $\mathrm{Sd}, \mathrm{m}$. to $\mathrm{c}$. & 0.26 & 0.84 & 3.23 & 0.39 & 58.19 & 47.21 & 14.18 & 3.33 & 4720 \\
\hline & -40 & -50 & Clayey sand. & 0.12 & 0.91 & 7.6 & 0.32 & 5.51 & & & & \\
\hline & 0.0 & -10 & Sd, m. to c. with $5 \%$ gvl. & 0.28 & 1.2 & 4.28 & 0.37 & 54.03 & & & & \\
\hline 12 & -10 & -20 & Sd, f. to v. c. with $7 \%$ gvl. & 0.22 & 0.89 & 4.04 & 0.38 & 37.31 & 49.84 & 48.0 & 1.04 & 4984 \\
\hline & -20 & -30 & Sd, m. to c. with $10 \%$ gvl. & 0.26 & 0.85 & 3.27 & 0.39 & 58.19 & & & & \\
\hline & -20 & -30 & Sd, m. to c. with $3 \%$ gvl. & 0.24 & 0.62 & 2.58 & 0.41 & 61.58 & & & & \\
\hline 13 & -30 & -40 & Sd, f. to c. with $6 \%$ gvl. & 0.31 & 1.91 & 6.2 & 0.33 & 41.55 & 58.47 & 55.40 & 1.05 & 5846 \\
\hline & -40 & -50 & Sd, m. to c., with $8 \%$ gvl. & 0.26 & 0.69 & 2.65 & 0.41 & 72.27 & & & & \\
\hline & 0.1 & -11 & Sd, m. to v. c. with $10 \%$ gvl. & 0.23 & 0.89 & 3.87 & 0.38 & 40.78 & & & & \\
\hline 14 & -11 & -21 & Clayey sand. & 0.19 & 0.95 & 5.0 & 0.35 & 19.78 & 31.67 & 28.99 & 1.09 & 3152 \\
\hline & -25 & -37 & Sd, m. to v. c. with $12 \%$ gvl. & 0.21 & 0.81 & 3.85 & 0.38 & 33.99 & & & & \\
\hline & 0.0 & -3 & Sd, f. to v. c. with $5 \%$ gvl. & 0.19 & 0.72 & 3.8 & 0.38 & 23.26 & & & & \\
\hline 15 & -3 & -6 & Clayey sand with $4 \%$ gvl. & 0.16 & 0.86 & 5.4 & 0.35 & 14.03 & 18.71 & 17.92 & 1.04 & 1870 \\
\hline & -6 & -9 & Clayey sand with $10 \%$ gvl. & 0.175 & 0.79 & 4.5 & 0.36 & 18.83 & & & & \\
\hline & -10 & -20 & Clayey sand. & 0.12 & 0.37 & 3.1 & 0.40 & 13.82 & & & & \\
\hline 18 & -20 & -30 & Sd, m. to v. c. with $10 \%$ gvl. & 0.22 & 1.2 & 5.45 & 0.35 & 26.52 & 32.18 & 23.46 & 1.37 & 3218 \\
\hline & -30 & -40 & Sd, m. to c. with $12 \%$ gvl. & 0.27 & 0.99 & 3.7 & 0.38 & 56.19 & & & & \\
\hline & -5 & -8 & Clayey sand. & 0.13 & 0.39 & 3.0 & 0.40 & 16.22 & & & & \\
\hline 19 & -8 & -11 & Sd, f. to c. & 0.23 & 1.22 & 5.3 & 0.35 & 28.99 & 20.63 & 19.23 & 1.07 & 2062 \\
\hline & -11 & -14 & Clayey sand. & 0.16 & 0.72 & 4.5 & 0.365 & 16.67 & & & & \\
\hline & 0 & -5 & Sd, m. to c. with $8 \%$ gvl. & 0.23 & 0.64 & 2.78 & 0.41 & 55.97 & & & & \\
\hline 20 & -5 & -10 & Sd, f. to c. with $6 \%$ gvl. & 0.24 & 0.69 & 2.87 & 0.404 & 57.74 & 62.26 & 61.60 & 1.01 & 6123 \\
\hline & -10 & -17 & Sd, m. to c. with $4 \%$ gvl. & 0.27 & 0.77 & 2.85 & 0.40 & 69.98 & & & & \\
\hline
\end{tabular}

${ }^{*}$ Sd: sand f.: fine m.: medium c.: coarse v.c.: very coarse. gvl.: gravel u $=$ uniformity coefficient $\Phi=$ porosity. $K_{h}$ : horizontal hydraulic conductivity $K_{\dot{r}}$ vertical hydraulic conductivity T: transmissivity. 


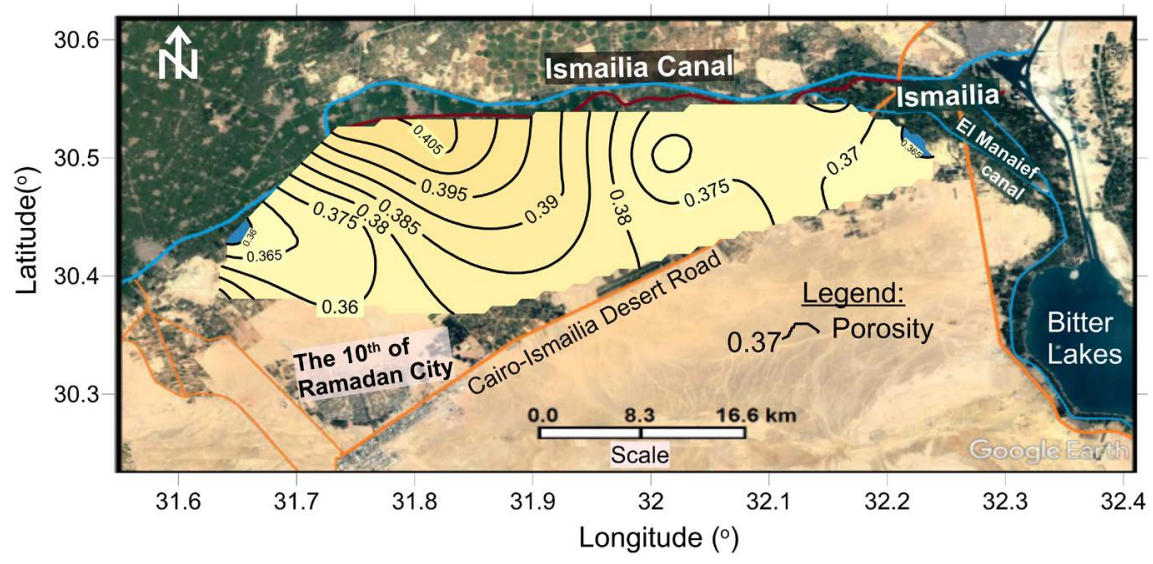

Figure 6. Contour map showing the distribution of average porosity, the Quaternary aquifer, west Ismailia area, Egypt.

\section{1) Kozeny-Hydraulic Conductivity $\left(K_{\text {Kozeny }}\right)$}

In this work, the hydraulic conductivity $(K)$ values of the aquifer horizons of each well were determined indirectly from grain size distribution by applying Kozeny equation [19] in [20]. Both the porosity function $(\Phi)$ and the effective size parameter $\left(D_{10}\right)$ are considered in the equation:

$$
K_{\text {Kozeny }}(m / \text { day })=5400\left[\Phi^{3} /(1-\Phi)^{2}\right]\left(D_{10}\right)^{2}
$$

The hydraulic conductivity ( $K_{\text {Kozeny }}$ ) estimated for each horizon varies greatly with depth. It ranges from $2.61 \mathrm{~m} /$ day (depth interval from $5 \mathrm{~m}$ to $0.0 \mathrm{~m}$, msl, well 3) to $106.6 \mathrm{~m} /$ day (depth interval from $-40 \mathrm{~m}$ to $-50 \mathrm{~m}$, msl, well no. 5) (Table 2). For each well, the average hydraulic conductivity of all horizons is calculated. The average $\mathrm{K}_{\text {(Kozeny) }}$ varies between $18.70 \mathrm{~m} /$ day and $65.49 \mathrm{~m} /$ day, with an average value of about $46.86 \mathrm{~m} /$ day.

\section{2) Effective Horizontal Hydraulic Conductivity $\left(K_{h}\right)$}

The effective horizontal hydraulic conductivity $\left(K_{h}\right)$ of the Quaternary was estimated using the following equations [21]:

$$
K_{h}(m / d a y)=\sum(m i K i) / \sum(m i)
$$

where $m i$ is thickness of the tested interval $(i), K i$ is the hydraulic conductivity of $\mathrm{i}^{\text {th }}$ interval.

The calculated horizontal hydraulic conductivity $\left(K_{h}\right)$ values are listed in Table 2 and their distribution through the Quaternary aquifer is shown in Figure 7. The $K_{h}$ of the investigated aquifer varies between $18.71 \mathrm{~m} /$ day in well no. 15 and $63.95 \mathrm{~m} /$ day in well no. 7 with an average value of about $46.6 \mathrm{~m} /$ day. It decreases due northeast with increasing the amount of fine grained clay and calcareous materials (see the cross section, Figure 4 ). The $K_{h}$ positively correlates with the average porosity $(r=0.73)$. In other words, the increase in the porosity of the aquifer materials leads to increasing the horizontal hydraulic conductivity. To a great extent, there is a consistency between the distribution of both the $K_{h}$ and $\Phi$ as shown in Figure 6 and Figure 7. 


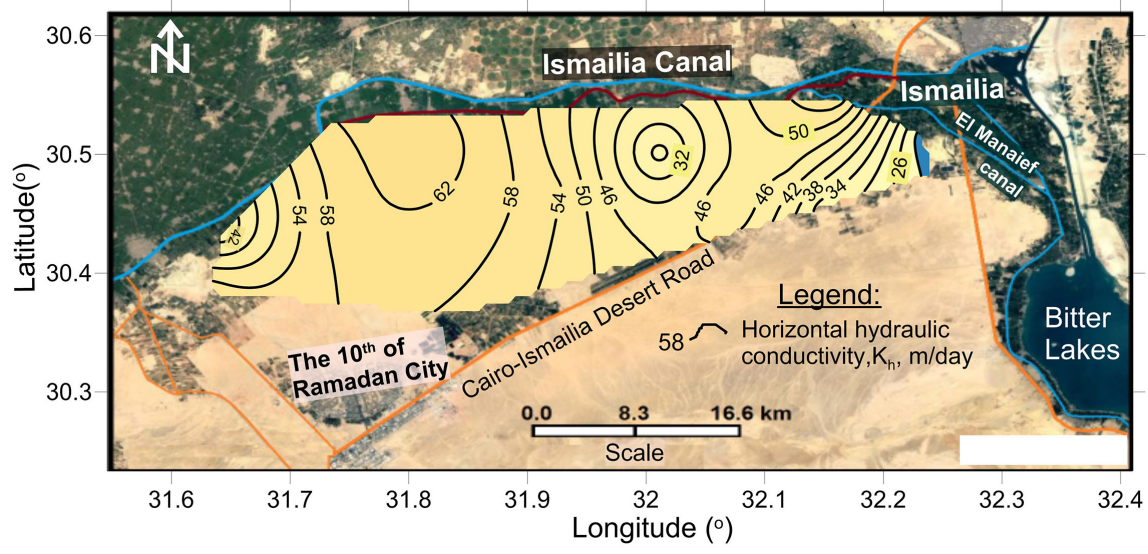

Figure 7. Contour map showing the distribution of the horizontal hydraulic conductivity of the Quaternary aquifer, west Ismailia area, Egypt.

\section{3) Effective Vertical Hydraulic Conductivity $\left(K_{v}\right)$}

The effective vertical hydraulic conductivity $\left(K_{v}\right)$ of the Quaternary aquifer was determined by applying the following equation [21]:

$$
K_{v}(m / \text { day })=\sum(m i) / \sum(m i / K i)
$$

The calculated vertical hydraulic conductivity $\left(K_{v}\right)$ of the concerned aquifer ranges from $8.94 \mathrm{~m} /$ day in well no. 3 to $61.6 \mathrm{~m} /$ day in well no. 20 (Table 2), with an average value of about $35.98 \mathrm{~m} /$ day. The distribution of $K_{v}$ values of the aquifer is shown in Figure 8. The maximum $K_{v}$ values are recorded in the area located between the longitudes $31.8^{\circ}$ and $32^{\circ} \mathrm{E}$, while the minimum values are recorded in the areas located due the west and east. The decrease in $K_{V}$ values is most probably due to the presence of the sedimentary horizons formed of fine grained clay mixed with sand, especially in the northeastern part of the area.

\subsubsection{Anisotropy $\left(K_{h} / K_{v}\right)$}

Study of the anisotropy of an aquifer is of great importance to reveal the homogeneity of aquifer materials and sedimentlogical manner. Anisotropy of the Quaternary-aquifer hydraulic conductivity was determined by dividing $K_{h}$ by $K_{V}$ [22]:

$$
\text { Anisotropy }=K_{h} / K_{v}
$$

Inspection in Table 2 reveals that the $K_{h}$ values are generally higher than $K_{V}$ ones, and this is imparted on the values of the anisotropy $\left(K_{h} / K_{V}\right)$ of the aquifer hydraulic conductivity. The $K_{h} / K_{V}$ values ranges from 1.01 to 4.27 (Table 2). For well nos. 3,5 and 11, the particle size analysis yields anisotropies such that the $K_{h}$ is typically about 3 to 4 times that of $K_{r}$. For the rest of wells a slight difference between $K_{h}$ and $K_{V}$ values is recorded. The anisotropy values decrease in the central part of the area and generally increase gradually eastwards and westwards (Figure 9).

Generally speaking, the recorded anisotropy values for the Quaternary aquifer are small. This is due to the absence of the bedding planes within the deposits of 
the aquifer and/or missing the smaller scale lithofacies such as very thin silt and clay beds having lower hydraulic conductivity values. The anisotropy values show that the Quaternary aquifer is heterogeneous and anisotropic.

\subsubsection{Transmissivity (T)}

Transmissivity $(T)$ of an aquifer is important evidence about its productivity. The higher the transmissivity the more the ground water an aquifer can produce. The transmissivity of the Quaternary aquifer is estimated based on the average hydraulic conductivity values $\left(K_{\text {kozeny }}\right)$ and the average saturated thickness $(H)$ of the aquifer $(100 \mathrm{~m})$. The transmissivity is expressed by the following equation:

$$
T\left(m^{2} / \text { day }\right)=K_{(k o z e n y)} \times H
$$

The $T$ values of the investigated aquifer horizons range from $1870 \mathrm{~m}^{2} /$ day (well no. 15) to $6549 \mathrm{~m}^{2} /$ day (well no. 17) as shown in Table 2. The average $\mathrm{T}$ value of the aquifer reaches $4686 \mathrm{~m}^{2} /$ day. According to [27] classification, the majority of the $\mathrm{T}$ values shows that the Quaternary aquifer is characterized by

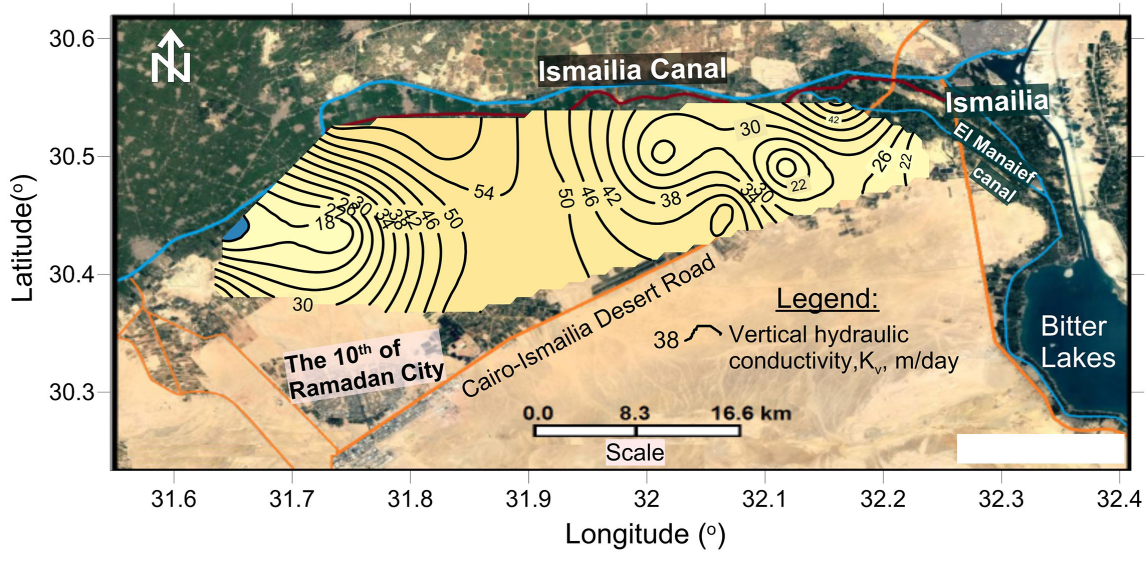

Figure 8. Contour map showing the distribution of the vertical hydraulic conductivity of the Quaternary aquifer, west Ismailia area, Egypt.

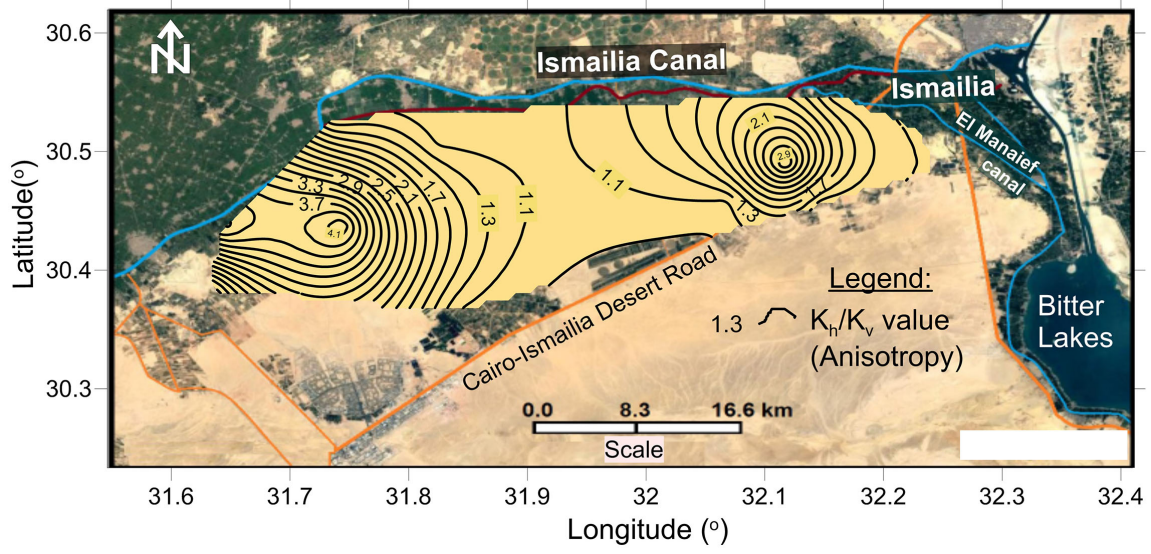

Figure 9. Contour map showing the distribution of the anisotropy $\left(K_{h} / K_{v}\right)$ of the Quaternary aquifer-hydraulic conductivity, west Ismailia area, Egypt. 
high potential $\left(\mathrm{T}>500 \mathrm{~m}^{2} /\right.$ day). The $\mathrm{T}$ values estimated based on the grain size analysis are, to some extent; in agree with those obtained from pumping tests [28]. Figure 10 shows the spatial distribution of $\mathrm{T}$ values in the Quaternary aquifer. The $\mathrm{T}$ generally decreases northeastwards due to the increase in clay and calcareous material content.

\subsection{Depth to Water Level}

Depths to water levels from ground surface in wells tapping the Quaternary aquifer are shown in Table 3. They vary greatly from site to another site according to the topographic elevations. They range from less than $5.0 \mathrm{~m}$ (shallow ground water) in the northern cultivated part of the area to about $70 \mathrm{~m}$ (deep ground water) in the southern desert area (Figure 11). The decrease in ground elevation is generally associated with a decrease in the depth to water level. Information dealing with depth to water map plays an important role in case of drilling new wells in new sites in the study area.

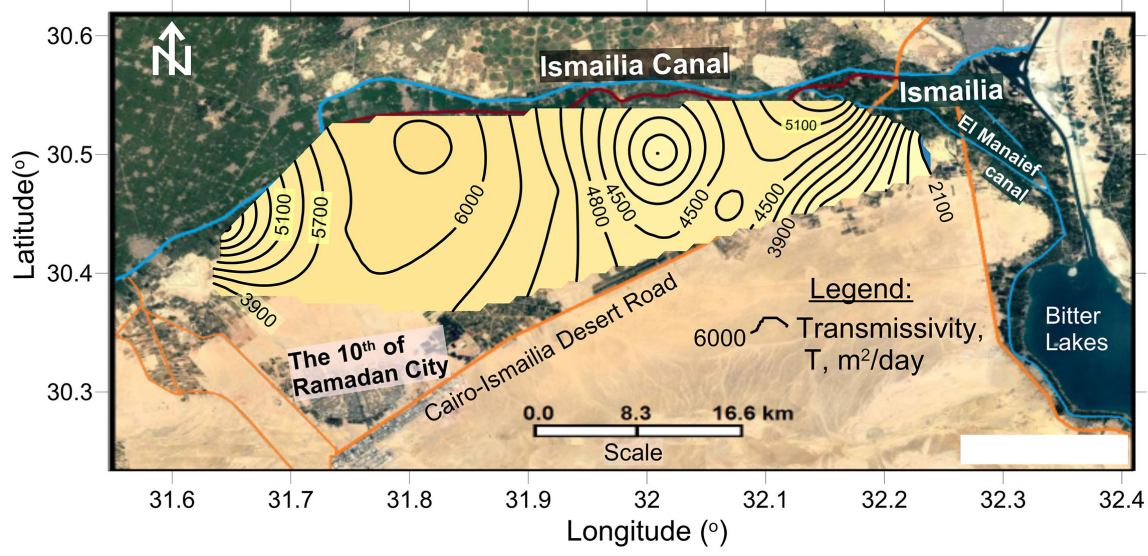

Figure 10. Contour map showing the distribution of the transmissivity ( $\mathrm{T}$ ) of the Quaternary aquifer, west Ismailia area, Egypt.

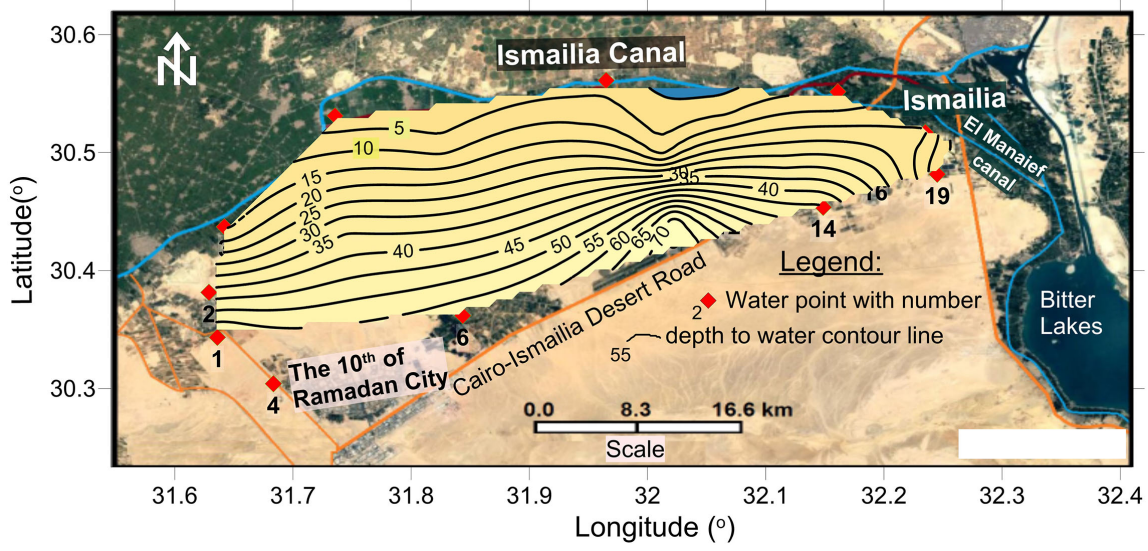

Figure 11. Contour map showing the depth to water level, the Quaternary aquifer, west Ismailia area. 
Table 3. Coordinates, elevations and ground water level data, the Quaternary aquifer, west Ismailia area, Egypt.

\begin{tabular}{|c|c|c|c|c|c|c|c|}
\hline $\begin{array}{c}\text { Well } \\
\text { number }\end{array}$ & $\begin{array}{l}\text { Long. } \\
\text { (o) }\end{array}$ & $\begin{array}{l}\text { Lat. } \\
\text { (o) }\end{array}$ & $\begin{array}{c}\text { Well } \\
\text { depth, m }\end{array}$ & $\begin{array}{c}\text { Well } \\
\text { Diameter, } \\
\text { inch }\end{array}$ & $\begin{array}{l}\text { Ground } \\
\text { altitude, m } \\
\text { (MSL) }\end{array}$ & $\begin{array}{l}\text { Depth to } \\
\text { water, } m\end{array}$ & $\begin{array}{l}\text { Ground } \\
\text { water } \\
\text { altitudes, } \\
\mathrm{m}, \text { (MSL) }\end{array}$ \\
\hline 1 & 31.63608 & 30.34339 & 125 & 10 & 70 & 58.7 & 11.3 \\
\hline 2 & 31.62889 & 30.38143 & 90 & 10 & 52 & 41.8 & 10.2 \\
\hline 3 & 31.64205 & 30.43707 & 90 & 8 & 23 & 13.5 & 9.5 \\
\hline 4 & 31.68343 & 30.30399 & 120 & 10 & 105 & - & - \\
\hline 5 & 31.74402 & 30.4368 & 95 & 10 & 43 & 33.5 & 9.5 \\
\hline *6 & 31.84362 & 30.36179 & 125 & 12 & 70 & 58.6 & 11.4 \\
\hline 7 & 31.82569 & 30.50764 & 40 & 6 & 13 & 6.6 & 6.4 \\
\hline 8 & 31.94441 & 30.52934 & 45 & 10 & 15 & 8.5 & 6.5 \\
\hline *9 & 32.02236 & 30.44387 & 127 & 12 & 84 & 71.9 & 12.1 \\
\hline 10 & 31.92694 & 30.47106 & 90 & 10 & 42 & 33.2 & 8.8 \\
\hline 11 & 32.11726 & 30.49074 & 96 & 10 & 41 & 28 & 13 \\
\hline${ }^{*} 12$ & 32.06791 & 30.45609 & 130 & 12 & 79 & - & - \\
\hline 13 & 32.16098 & 30.55159 & 58 & 6 & 10 & 4 & 6.0 \\
\hline$* 14$ & 32.14865 & 30.45366 & 110 & 10 & 61 & 46.04 & 14.96 \\
\hline 15 & 32.23514 & 30.51709 & 22 & 2 & 17 & 16 & 1.0 \\
\hline 16 & 32.19223 & 30.48485 & 72 & 8 & 33 & 25.5 & 7.5 \\
\hline 17 & 32.06593 & 30.53752 & 26 & 2 & 10 & 2.78 & 7.22 \\
\hline 18 & 32.01157 & 30.50075 & 52 & 8 & 17 & 7.6 & 9.4 \\
\hline 19 & 32.24513 & 30.48159 & 24 & 2 & 21 & 6.45 & 14.55 \\
\hline 20 & 31.73563 & 30.53114 & 18 & 2 & 11 & 1.5 & 9.5 \\
\hline 21 & 31.67282 & 30.38579 & 120 & 10 & 65 & 54.8 & 10.2 \\
\hline $\begin{array}{c}22 \\
\text { (Ismailia } \\
\text { canal) }\end{array}$ & 31.96496 & 30.56109 & - & - & 13 & 3.5 & 9.5 \\
\hline $\begin{array}{l}23 \text { (El Mah- } \\
\text { sama drain) }\end{array}$ & 31.98489 & 30.54756 & - & - & 9 & 3 & 6 \\
\hline $\begin{array}{c}24 \text { (El Ma- } \\
\text { naief canal) }\end{array}$ & 32.26325 & 30.51055 & - & - & 9 & 2 & 7 \\
\hline
\end{tabular}

*: Well tapping the Quaternary and Miocene aquifers.

\subsection{Ground Water Flow}

The ground water altitudes of the Quaternary aquifer (Table 3 ) are graraphically represented as a potentiometric surface contour map (Figure 12). All ground 
water levels measured for the aquifer are found above mean sea level. They range from less than $7.0 \mathrm{~m}$ at the northern part of the area to less than $15 \mathrm{~m}$ at the southeast.

The Quaternary aquifer is characterized by a multiple and divergent water flow paths that seems to be the product of the structural setting, heterogeneity and anisotropy. The ground water generally flows from the recharge areas to the discharge ones. The directions of flow lines refer to the recharge from the Miocene aquifer and occasional flash flood in the south and from Ismailia and El Manaief canals in the north and east. The ground water depressions (sites A and $B$ in Figure 12) are the discharge areas. Site A (El Mahsama lake) is a natural discharge area for the groundwater, while site $B$ is adown cone originated due to heavy pumping as has been observed during the field works.

The hydraulic gradient (I) as a factor controlling the ground water movement is calculated from the differences in hydraulic heads (dh) per unit length (dI) over the lengths of the flow paths. It is irregular and, generally, decreases westwards and increases eastward (Figure 12). The hydraulic gradient in the eastern part of the study area (east of the longitude $32.1^{\circ} \mathrm{E}$ ) is very steep, ranging from 0.001 to 0.0066 and average about 0.0034 , while in the area between the longitudes $31.9^{\circ}$ and $32.1^{\circ} \mathrm{E}$ it is relatively steep ranging from 0.0004 to 0.00055 and average about 0.00438 . In the western part (west of the longitude $31.9^{\circ} \mathrm{E}$ ), the hydraulic gradient is relatively flat, ranging from 0.00025 to 0.00020 with an average value of about 0.00022 .

The flat and steep hydraulic gradients in the western and eastern parts of the study area could be attributed to the difference in discharge rates. The withdrawal from the aquifer in western area became very low in recent years because this area has been provided with freshwater from Ismailia canal through subsurface pipelines. And on the contrary of that, the need to the ground water in eastern area has been increased, and consequently a large number of discharging wells have been completed.

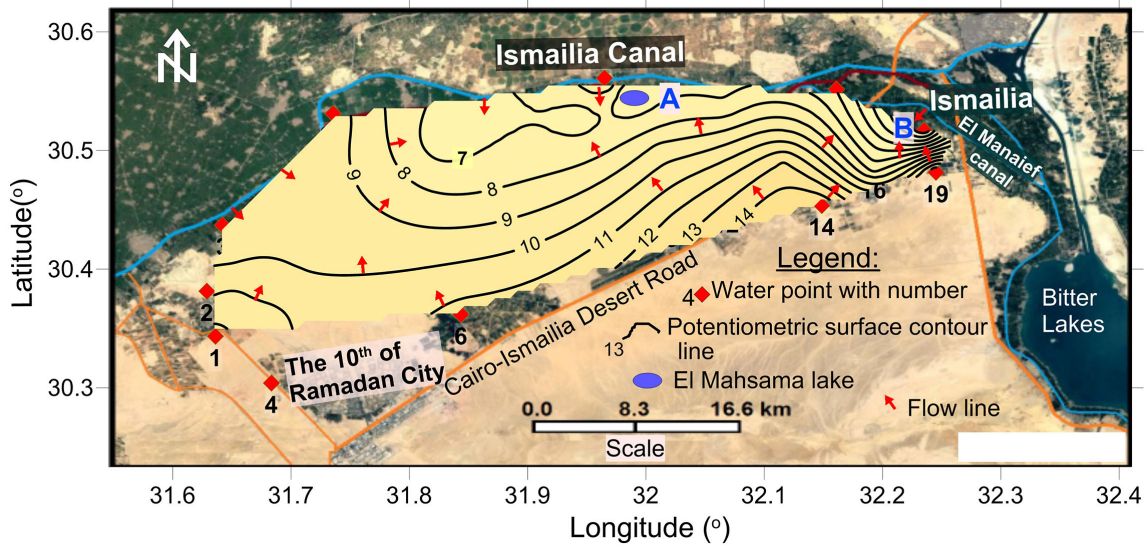

Figure 12. Contour map showing the potentiometric surface and ground water flow (Jan. 2017), the Quaternary aquifer, west Ismailia area, Egypt. 


\subsection{Recharge of the Quaternary Aquifer and Darcy Velocity}

The potentiometric surface contour map (Figure 12) shows that the Quaternary aquifer is recharged from the area located at the south; indeed this is besides the recharge from the surface water canals in the north and northeast. Herein, the recharge from the southern area is considered, and it is estimated according to Darcy equation [23]:

$$
Q=K_{h} \times L \times B \times I
$$

where $Q$ is the amount of recharge to the Quaternary aquifer $\left(\mathrm{m}^{3} /\right.$ day) calculated from Darcy law, $K$ is the average horizontal hydraulic conductivity ( $46.6 \mathrm{~m} /$ day), $L$ is the length of the front to recharge area $(60 \mathrm{~km}), B$ is the average aquifer thickness $(100 \mathrm{~m})$ and $I$ is the average hydraulic gradient (0.00438). Accordingly, the aquifer in the study area is recharged from the south by an amount of water that attains $1.22 \times 10^{6} \mathrm{~m}^{3} /$ day $\left(447 \times 10^{6} \mathrm{~m}^{3} /\right.$ year $)$.

Darcy velocity, $V$ (Darcy flux or specific discharge) of ground water of the Quaternary aquifer in the study area is estimated using the following Darcy's equation:

$$
V=Q /(L \times B)
$$

The estimated Darcy's velocity of the ground water in the Quaternary aquifer is $0.203 \mathrm{~m} /$ day, on average.

\subsection{Change in the Hydrologic Setting}

To examine the change in the hydrologic setting of the Quaternary aquifer in the study area during the period of 1992-2017, the water table contour maps constructed for the year 1992 [29] (Figure 13), for the year 2005 [30] (Figure 14) and for the year 2017 (the present work) are compared. The comparison process reveals that:

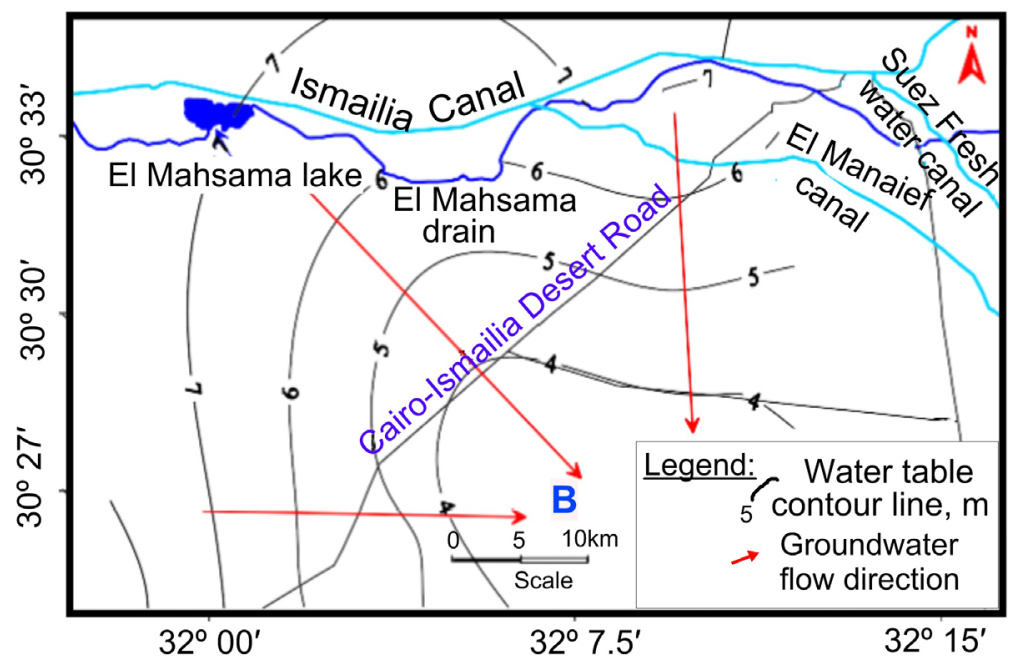

Figure 13. Water table contour map (Dec., 1992) [29]. 


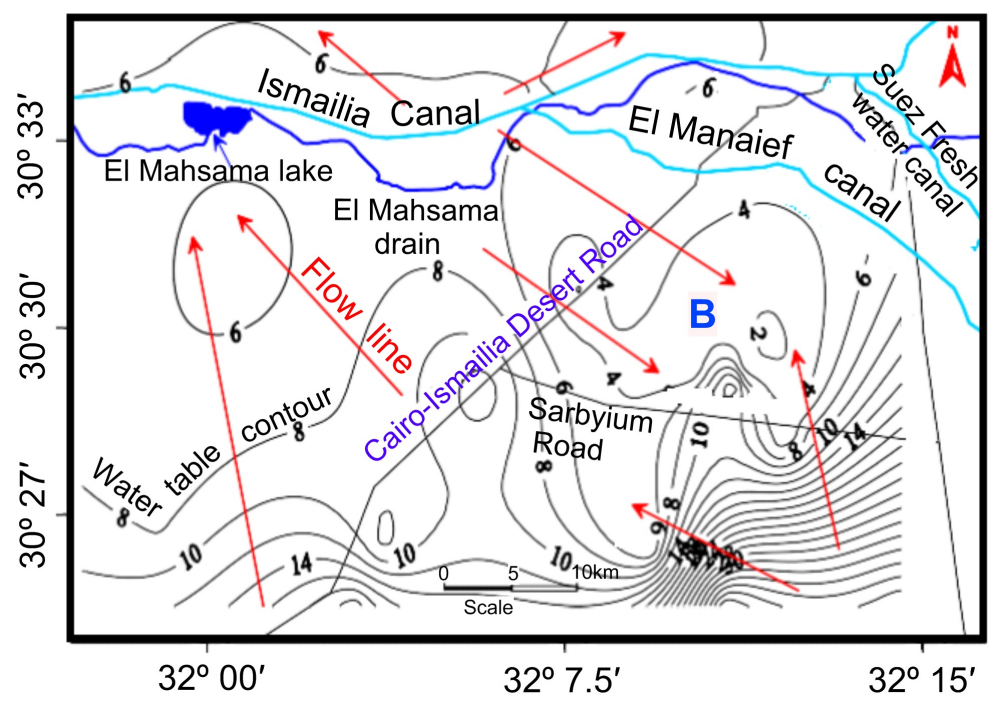

Figure 14. Water table contour map (Dec., 2005) [30].

1) During the period of 1992-2005, a great change in the hydrology of ground water is occurred, where a great number of production wells have been completed in the northeastern part of the area. As a result of that the down cone area (B) is displaced towards the north.

2) In the year 1992, the flow of ground water was from the north (Ismailia Canal) and east to the west (site B in Figure 13), while in the year 2005 the ground water flow was from the north and south to the discharge area (site B in Figure 14).

3) From the period 2005 to 2017 years, there is no observed change in the hydrologic situation of the area, where the arrangement of water table contour lines and the place of the down cone area (site B) is nearly the same as shown in Figure 12 and Figure 14. During that period, Ismailia and El Manaief canal act as influent streams, i.e. they represent a recharge sources to the Quaternary aquifer.

\subsection{Aqueous Environment of the Quaternary Aquifer}

The phsico-chemical parameters that have been measured in situe for the ground water samples of the Quaternary aquifer and surface water samples of the main canals are listed in Table 4. They are described as follows:

\subsubsection{Temperature and $\mathrm{pH}$}

Water temperature and $\mathrm{pH}$ affect many physical, chemical and biological properties of water systems [31]. The measured temperature of the ground water of the Quaternary aquifer does not vary considerably. They range between $25.33^{\circ} \mathrm{C}$ and $28.36^{\circ} \mathrm{C}$, with an average value of about $26.69^{\circ} \mathrm{C}$. The surface water temperature $\left(26.28^{\circ} \mathrm{C}-28.41^{\circ} \mathrm{C}\right)$ has slightly influence on the ground water one, because most of the ground water is not shallow. 
Table 4. Physico-chemical parameters of the Quaternary ground water and surface water samples, west Ismailia area, Egypt.

\begin{tabular}{|c|c|c|c|c|c|c|c|}
\hline $\begin{array}{l}\text { Water } \\
\text { point }\end{array}$ & $\begin{array}{c}\mathrm{T} \\
\left({ }^{\circ} \mathrm{C}\right)\end{array}$ & $\begin{array}{c}\mathrm{DO} \\
(\mathrm{mg} / \mathrm{l})\end{array}$ & $\begin{array}{l}\text { ORP } \\
(\mathrm{mV})\end{array}$ & $\begin{array}{c}\mathrm{Eh} \\
(\mathrm{mV})\end{array}$ & $\begin{array}{l}\text { Sp. Cond. } \\
(\mu \mathrm{S} / \mathrm{cm})\end{array}$ & $\mathrm{pH}$ & $\begin{array}{l}\text { TDS } \\
(\mathrm{mg} / \mathrm{l})\end{array}$ \\
\hline 1 & 26.52 & 4.58 & 187 & 386 & 4901 & 7.2 & 3088 \\
\hline 2 & 26.77 & 7.21 & 324 & 401 & 2950 & 6.19 & 1888 \\
\hline 3 & 27.18 & 7.13 & 305 & 504 & 632.5 & 6.36 & 404 \\
\hline 4 & 26.13 & 5.31 & 221 & 420 & 3488 & 7.41 & 2100 \\
\hline 5 & 27.20 & 4.99 & 199 & 398 & 4571 & 7.3 & 2834 \\
\hline 6 & 26.11 & 4.33 & 159 & 358 & 9650 & 6.10 & 6210 \\
\hline 7 & 26.84 & 5.29 & 195 & 394 & 4759 & 7.29 & 2980 \\
\hline 8 & 26.75 & 3.41 & 9 & 208 & 4811 & 5.7 & 3074 \\
\hline 9 & 26.12 & 7.46 & 164 & 363 & 10060 & 6.01 & 6440 \\
\hline 10 & 26.19 & 3.42 & 176 & 375 & 6210 & 6.21 & 3899 \\
\hline 11 & 27.53 & 4.18 & 231 & 430 & 3970 & 6.0 & 2544 \\
\hline 12 & 26.24 & 3.56 & 235 & 434 & 8089 & 6.33 & 5250 \\
\hline 13 & 28.36 & 3.38 & -9 & 185 & 501.9 & 6.36 & 325.6 \\
\hline 14 & 25.32 & 3.68 & 255 & 454 & 11530 & 5.28 & 7383 \\
\hline 15 & 27.34 & 2.13 & 132 & 331 & 978 & 6.96 & 626.1 \\
\hline 16 & 27.19 & 5.71 & 208 & 407 & 3856 & 6.29 & 2473 \\
\hline 17 & 26.29 & 8.40 & 637 & 836 & 503.2 & 6.28 & 322 \\
\hline 18 & 25.62 & 4.09 & 233 & 432 & 3563 & 5.93 & 2281 \\
\hline 19 & 27.27 & 2.5 & 196 & 395 & 4659 & 6.07 & 2984 \\
\hline 20 & 27.12 & 5.49 & 24 & 223 & 798 & 5.65 & 511.4 \\
\hline 21 & 26.44 & 4.11 & 184 & 383 & 4564 & 6.7 & 2890 \\
\hline 22 (Ismailia Canal) & 28.41 & 8.89 & 85 & 279 & 424.8 & 7.9 & 271.4 \\
\hline 23 (El Mahsama drain) & 26.28 & 3.09 & 129 & 323 & 2647 & 6.13 & 1694 \\
\hline 24 (El Manaief canal) & 28.22 & 9.02 & 228 & 422 & 445.3 & 7.13 & 285.2 \\
\hline
\end{tabular}

T: Temperature degrees DO: dissolved oxygen ORP: oxidation reduction potential. Eh: redox potential TDS: total dissolved solids Sp. Cond.: specific conductivity.

The Quaternary aquifer has $\mathrm{pH}$ values ranging from 5.28 to 7.41 standard units, showing that the ground water ranges from acid to slightly alkaline. No obvious trend as regard the distribution manner of the $\mathrm{pH}$ in the aquifer (Figure 15). However, in the eastern part of the area, the $\mathrm{pH}$ is found to increase north-eastwards to attain 6.96 (well no. 15), which is greatly similar to that of the El Manaief canal-recharge source ( $\mathrm{pH}=7.13$ standard units). Furthermore, the occurrence of more acidic ground water in some places (well nos. 8, 14, 18 and 20) with $\mathrm{pH}$ less than 6 standard units may reflect: 1) the recharge from acidic surface water bodies, especially those found in the western industrial area, 2) re- 
lease of hydrogen ions due to oxidation of pyrite mineral that usually found in the alluvial sediments, 3) escape of carbon dioxide to shallow groundwater, which forms carbonic acid that may dissociate into bicarbonate and hydrogen ions, and consequently decrease the $\mathrm{pH}$ of ground water, and 4) Infiltration of acidic precipitation to ground water, especially in the southern part of the area.

The Egyptian High Committee of Water [32] recommends a $\mathrm{pH}$ range from 6.5 to 8.5 standard units for public supply. About $29 \%$ of ground water samples are within this range. The rest of samples (71\%) of the ground water samples are out of the recommended range where the measured $\mathrm{pH}$ values are less than 6.5 standard units.

\subsubsection{Specific Conductance and Salinity}

The specific conductance reflects the quantity of materials dissolved in water. The water of some wells (nos. 3, 13, 15, 17 and 20) and surface water of Ismailia and El Manaief canals in the investigated area are largely dilute water where the measured specific conductance values are less than $1000 \mu \mathrm{S} / \mathrm{cm}$ (Table 4). This reflects low degree of chemical evolution. El Mahsama drain water has relatively higher specific conductance value $(2647 \mu \mathrm{S} / \mathrm{cm})$ than the fresh water canals. The rest of wells produce brackish to saline water, where the specific conductance values range from $2950 \mu \mathrm{S} / \mathrm{cm}$ to $11530 \mu \mathrm{S} / \mathrm{cm}$. This reflects the local variation in hydrogeologic characteristics and recharge sources. Generally, the specific conductance of ground water is typically one and half times the total dissolved solids, in $\mathrm{mg} / \mathrm{l}$.

Salinity (as total dissolved solids, TDS) of the Quaternary aquifer in the concerned area ranges from $322 \mathrm{mg} / \mathrm{l}$ (well no. 17) in the north to $7383 \mathrm{mg} / \mathrm{l}$ (well no. 14) in the south, and the average value is $2881 \mathrm{mg} / \mathrm{l}$. There is a wide variation in the concentration of total dissolved solids in the aquifer as shown in Figure 16. Close to Ismailia and El Manaief canals, a stretcher of fresh water extends in the east-west direction. This may be due to increase in feeding velocity with fresh water from Ismailia and El Manaief canals having low salinity $(271<$ TDS $<285)$. The salinity increases gradually southwards to attain its maximum value (TDS $>7000 \mathrm{mg} / \mathrm{l}$ ) close to Cairo-Ismailia Desert Road, which might be evidence of more evolved water due to the effect of hydrogeochemical processes and continuous recharge from the Miocene aquifer having high saline water [16]. The salinity distribution map (Figure 16) is with conformable with the potentiometric surface contour map (Figure 12) where the salinity decreases with decreasing the ground water level altitudes. The recommended maximum level of TDS value for public supply is $1000 \mathrm{mg} / \mathrm{l}$ [32]. Over $75 \%$ of ground water samples show TDS values exceeding the recommended level and the rest of samples show TDS values that are less than that level.

\subsubsection{Dissolved Oxygen and Redox Potential}

The solubility of oxygen in ground water is limited and directly related to the atmospheric pressure and inversely related to hydrostatic pressure [33]. The 


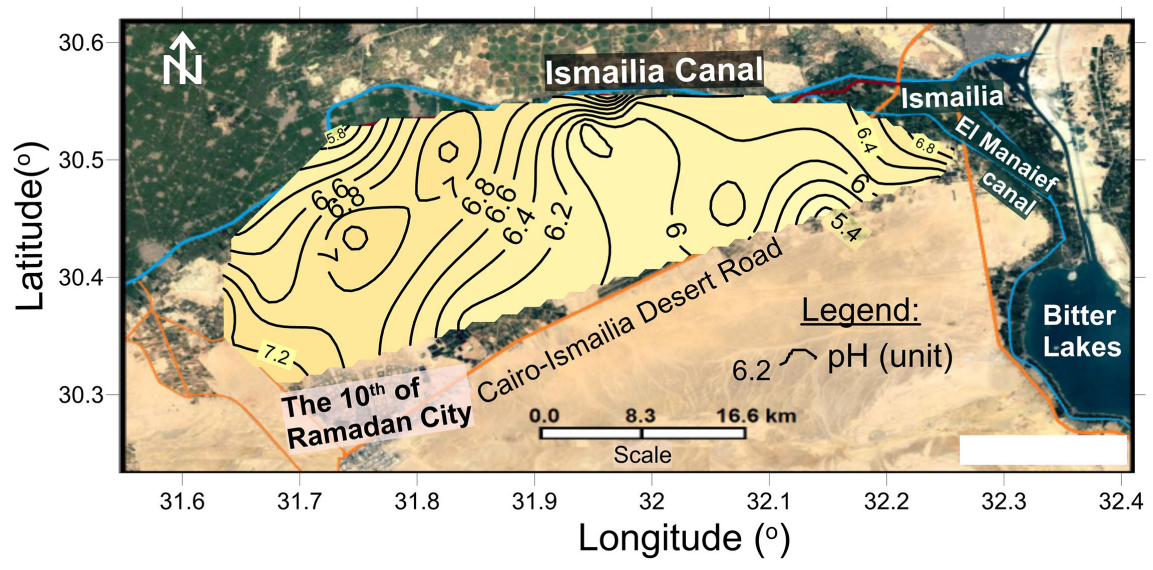

Figure 15. Contour map showing the distribution of $\mathrm{pH}$ in standard units in the Quaternary aquifer, west Ismailia area, Egypt.

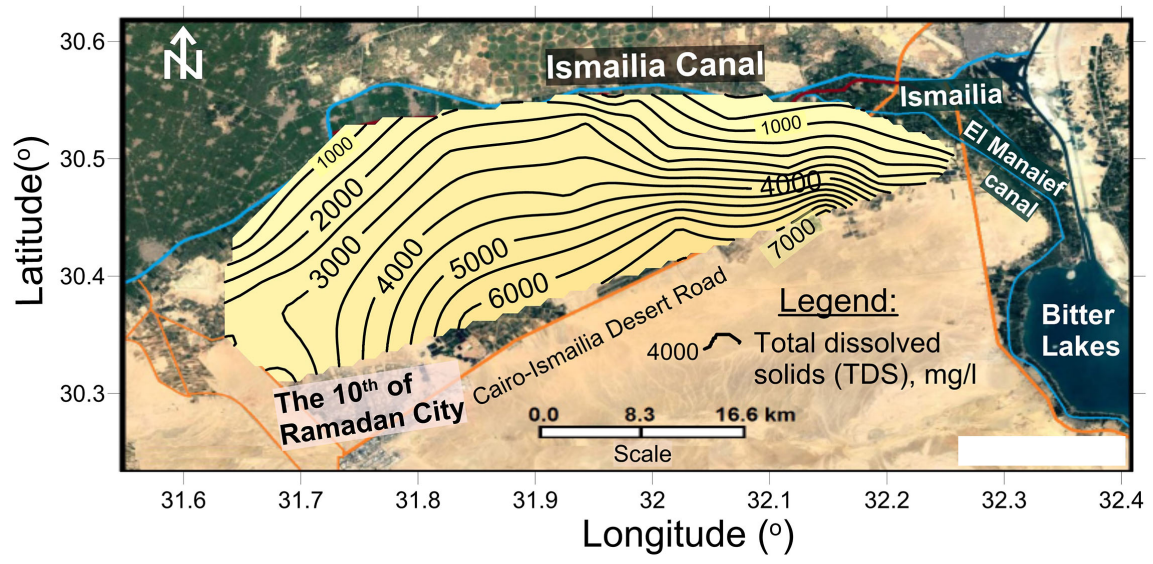

Figure 16. Contour map showing the distribution of total dissolved solids in $\mathrm{m} / \mathrm{l}$ in the Quaternary aquifer, west Ismailia area, Egypt.

fresh surface water bodies (Ismailia and El Manaief canals) have higher dissolved oxygen (DO) than in the ground water, the average being $8.95 \mathrm{mg} / \mathrm{l}$. Concentrations of DO in the Quaternary aquifer typically are between $2.13 \mathrm{mg} / \mathrm{l}$ (well no. 15) and $8.4 \mathrm{mg} / \mathrm{l}$ (well no. 17), with an average value of about $4.82 \mathrm{mg} / \mathrm{l}$. The presence of DO in appreciable amounts $(>1 \mathrm{mg} / \mathrm{l})$ in ground water probably indicates the transportation of oxygen from the surface and unsaturated zones to the aquifer and/or the effect of microbial reduction of DO is limited [34].

The distribution of the DO in the aquifer varies (Figure 17), and does not follow any pattern, which may reflect the recharge with different degrees from the fresh water canals. In some localized areas there are high content of DO, for instance well no. 17 in the north (see Figure 1) where the DO value attains 8.4 $\mathrm{mg} / \mathrm{l}$, which may indicate the significant recharge from surface water of Ismailia Canal. Also, the high concentration of DO $(7.46 \mathrm{mg} / \mathrm{l})$ recorded for well no. 9 in the south may indicate the recharge to the concerned aquifer from the occasional flash flood at the south. In conclusion, the high concentration of DO in the aquifer indicates the high velocity of water circulation. 


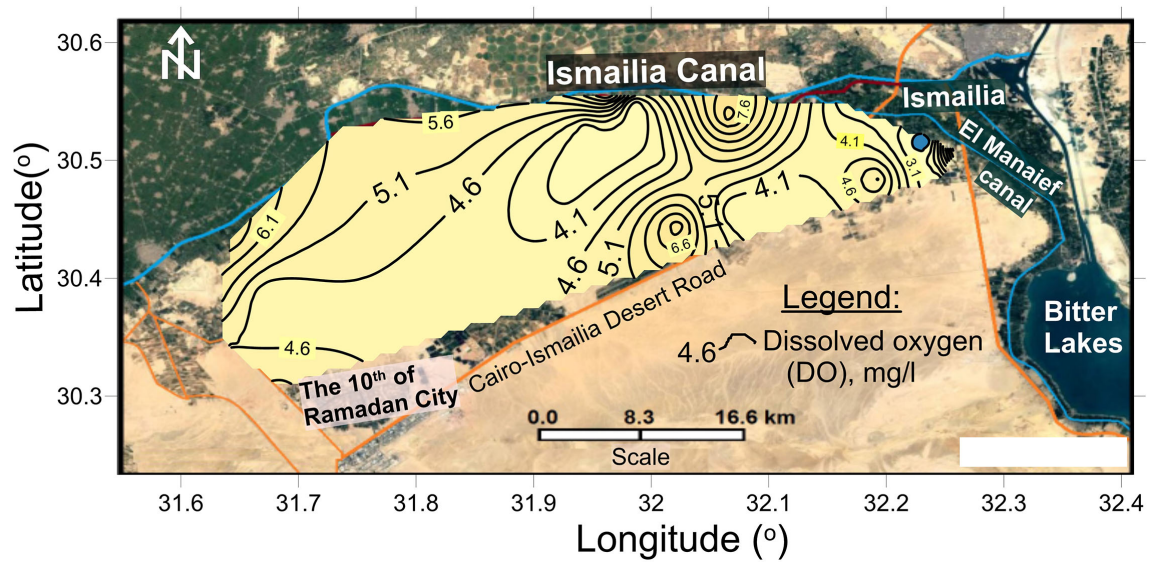

Figure 17. Contour map showing the distribution of dissolved oxygen in $\mathrm{mg} / \mathrm{l}$ in the $\mathrm{Qu}$ aternary aquifer, west Ismailia area, Egypt.

Redox potential (Eh, in $\mathrm{mV}$ ) is of great value for explaining how oxidations and reductions occurs in a water bearing formation. In the present work the Eh values are determined for the ground water samples based on the oxidation reduction potential measurements (ORP, in $\mathrm{mV}$ ) (Table 4). The Eh values vary greatly with location, ranging from $185 \mathrm{mV}$ (well no. 13) to $836 \mathrm{mV}$ (well no. 17); the average is $406 \mathrm{mV}$. Figure 18 shows that there is a general increase in the Eh values towards the north in the area located between the longitudes of $32^{\circ}$ and $32.1^{\circ} \mathrm{E}$, which is also the direction of DO increase. The Eh and DO are positively correlated $(r=0.53)$ (Figure 19(a)), suggesting that the geochemical controls on the Eh and DO parameters are to some extent similar. Moreover, there are no significant correlations between $\mathrm{Eh}$ and $\mathrm{DO}$ and the others physico-chemical parameters.

The ground water samples are plotted on the Eh-pH diagram [35] for aqueous environment (Figure 19(b)), which shows the reactions and products at electrochemical equilibrium. As shown in this diagram, the ground water samples are located in the region corresponding to oxidizing (alkaline) environment. The increase in Eh value, especially in the area of well no. $17(\mathrm{Eh}=836 \mathrm{mV})$ suggests that the ground water of Quaternary aquifer system in this area is more oxidizing (more electron losses), and therefore, metal dissolution is favored.

\section{Conclusions}

The conclusions of this study are as follows:

1) The Quaternary aquifer, representing the main source of ground water in west Ismailia area, comprises heterogeneous and anisotropic section of fluviatile sand and gravel. The ground water is shallow at the north and deep at the south, and exists under semi-confined to unconfined conditions.

2) Analysis of grain size distribution reveals that the aquifer hydraulic parameters (total porosity, horizontal and vertical and hydraulic conductivities, anisotropy, and transmissivity) are high indicating the high productivity of the aquifer. 


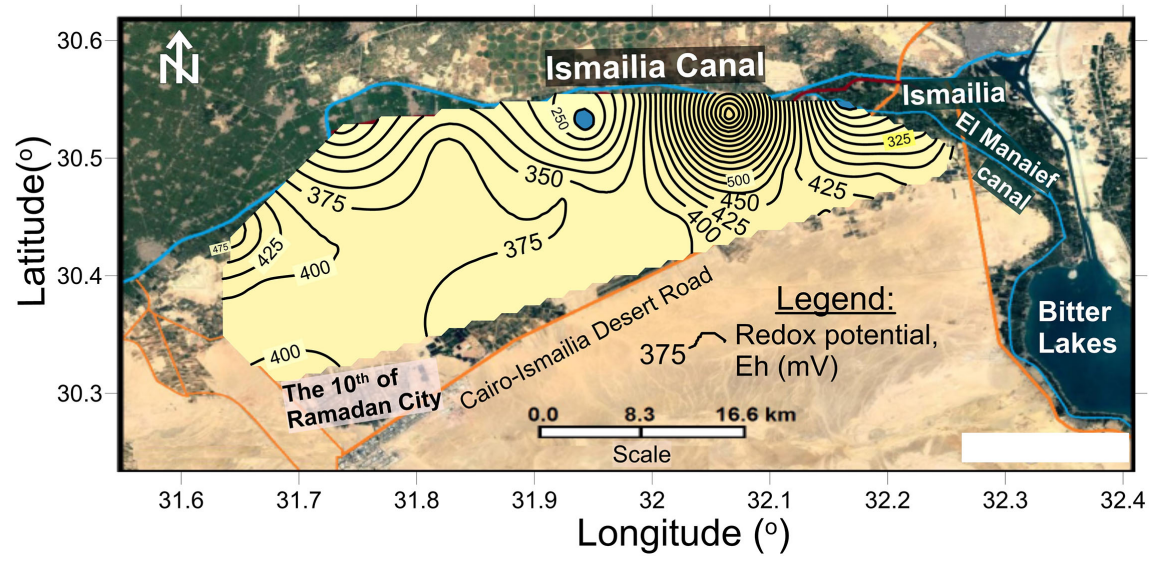

Figure 18. Contour map showing the distribution of redox potential in $\mathrm{mV}$ in the Quaternary aquifer, west Ismailia area, Egypt.

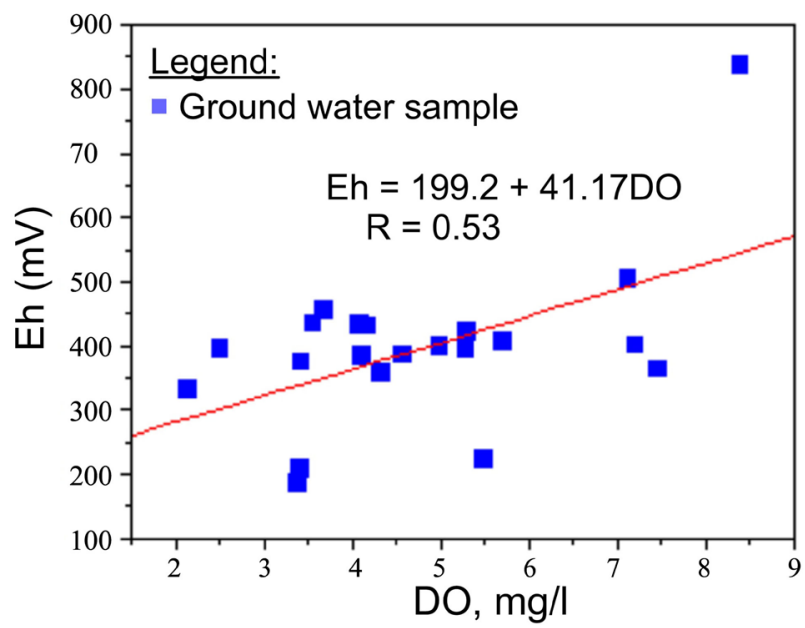

(a)

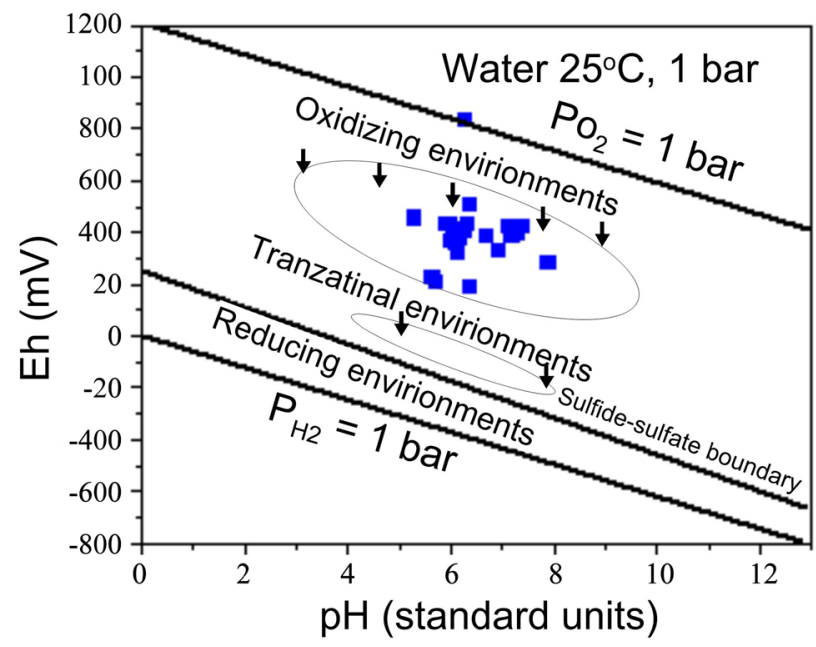

(b)

Figure 19. Relationships between the measured physicochemical parameter; (a) Eh-DO diagram and (b) Eh-pH diagram, the diagonal lines in (b) define the upper and lower stability limits for water at $25^{\circ} \mathrm{C}$ and 1 bar of pressure. 
Such parameters generally decrease eastwards as revealed from the spatial distribution maps.

3) Analysis of ground water altitudes indicates that the aquifer receives recharge from the fresh water canals due the north and northeast and from the Miocene aquifer and occasional flash flood due the south. The recharge rate from the southern area attains $1.22 \times 10^{6} \mathrm{~m}^{3} /$ day.

4) The hydrologic situation of the aquifer changed during the last 25 years, as revealed from the comparison of potentiometric surface contour map prepared by the present work with those constructed for the years 1992 and 2005.

5) Results of physico-chemical analysis indicate the influence of recharge sources and geological conditions on the quality of aqueous environment of the aquifer. The salinity of ground water is high at the south (TDS $=7383 \mathrm{mg} / \mathrm{l}$ ), and decreases gradually to attain its minimum value (TDS $=322 \mathrm{mg} / \mathrm{l}$ ) at the north. The constructed $\mathrm{pH}$-Eh diagram shows the oxidizing environment of the aquifer.

\section{Conflicts of Interest}

The authors declare no conflicts of interest regarding the publication of this paper.

\section{References}

[1] El-Shazly, E.M., Abdel Hady, M.A., El-Shazly, M.M., El-Ghawaby, M.A., El-Kassas, I.A., Salman, A.B. and Morsi, M.A. (1975) Geological and Groundwater Potential Studies of El Ismaillia Master Plan Study Area. Remote Sensing Research Project, Academy of Scientific Research and Technology, Cairo, 24 p.

[2] El Shamy, I.Z. and Geriesh, M.H. (1991) Hydrogeology of West Ismailia Area, Egypt. Desert Institute Bulletin, Egypt, 42, 271-288.

[3] El Shamy, Z. (1992) Hydrogeology of Wadi El Tumilat and Surroundings, East of the Nile Delta, Egypt.

[4] Korany, E.A., Atwa, S.M., Abdel Baki, A.A. and Gad, M.I. (1997) Hydrogeochemical Regime and Functions of the Groundwater in the Area East of the Tenth of Ramadan City, Egypt.

[5] Embaby, A.A. and El-Haddad, I.M. (2007) Environmental Impact of Wastewater on Soil and Groundwater at the Tenth of Ramadan City Area, Egypt. Mansoura Journal of Geology and Geophysics, 34, 25-56.

[6] Embaby, A.A., Sadek, M.A. and Rayan, R.A. (2017) Natural Attenuation Capacity Indicators for Groundwater Remediation to the Northeastern Cairo. Journal of Geoscience and Environment Protection, 5, 152-168. https://doi.org/10.4236/gep.2017.54012

[7] Hussien, R., Hagagg, K. and El-Aassar, A.M. (2017) Coupling HYDRUS and MODFLOW for Studying Environmental Impact of Wastewater Ponds in Tenth of Ramadan City, Egypt. The International Journal of Engineering and Science, 6, 41-54.

[8] EMA (Egyptian Meteorological Authority) (1996) Climatic Atlas of Egypt. Egyptian Meteorological Authority, Ministry of Transport and Communications, Arab Re- 
public of Egypt, 157 p.

[9] Gad, M.I., El-Kammar, M.M. and Ismail, H.M.G. (2015) Groundwater Vulnerability Assessment Using Different Overlay and Index Methods for Quaternary Aquifer of Wadi El-Tumilat, East Delta, Egypt. Asian Review of Environmental and Earth Sciences, 2, 9-22.

[10] Shata, A.A. and El Fayoumy, I.F. (1970) Remarks on the Regional Geological Structure of the Nile Delta. Proceeding of the Bucharest Symposium on Hydrogeology of Deltas, Romania, 6-14 May 1969, Vol. 1, 189-197.

[11] Mabrouk, B., Ramadan, F., Nagaty, M. and Abd El Azeem, Y. (2016) Sedimentlogical and Hydrogeochemical Studies of the Quaternary Groundwater Aquifer in El Salhyia Area, Sharkia Governorate, Egypt. Middle East Journal of Applied Sciences, 6, 120-138.

[12] El Diasty, M.E. (1969) The Aeromagnetic Map of the Delta Area and the Interpretation of the Geophysical Data. Unpublished M.Sc. Thesis, Faculty of Science-Alexandria University, Alexandria.

[13] El-Dairy, M.D. (1980) Hydrogeological Studies on the Eastern Part of Nile Delta Using Isotopes Techniques. M.Sc. Thesis., Faculty of Science, Al-Azhar University, Cairo, $233 \mathrm{p}$.

[14] CONOCO (1987) Geological Maps of Egypt Scale 1:500000, Sheet Nos. NG 36 NW Cairo \& NH 36 SW Beni Suef, with Cooperation of Egyptian General Petroleum Coroporation. Techisch Fachhochschule, Berlin.

[15] Said, R. (1962) The Geology of Egypt. Elsevier Pupl. Co., Amsterdam, 377.

[16] Sallouma, M.K.M. (1983) Hydrogeological and Hydrochemical Studies East of the Nile Delta, Egypt. PhD Thesis, Ain Shams University, Cairo.

[17] Striggow, B. (2017) Field Measurement of Oxidation Reduction Potential (ORP). SESD Operating Procedure, SESDPROC-113-R2, Field Measurement of ORP (113), AF.R2, USEPA, Science and Ecosystem Support Division, Athens, Georgia. https://www.epa.gov/sites/production/files/2017-07/documents/field_measurement _of_orp113_af.r2.pdf

[18] Vukovic, M. and Soro, A. (1992) Determination of Hydraulic Conductivity of Porous Media from Grain-Size Composition. Water Resources Publications, LLC Highlands Ranch, Clorado.

[19] Kozeny, J. (1953) Hydraulik. Springer, Wien, 588. https://doi.org/10.1007/978-3-7091-7592-7

[20] Boukhemacha, M.A., Gogu, R.C. and Bica, I. (2012) Flow Modeling of Urban Hydrogeological Systems. Mathematical Modeling in Civil Engineering, No. 2, 92 p.

[21] Domenico, P.A. and Schwartz, F.W. (1990) Physical and Chemical Hydrogeology. John Wiley and Sons, New York, $824 \mathrm{p}$.

[22] Kruseman, G.P. and de Ridder, N.A. (1994) Analysis and Evaluation of Pumping Test Data. 2nd Edition, lLRI, Publication 47, 377 p.

[23] Darcy, H. (1856) Les fontaines publiques de la ville de Dyon. V. Dalmont, Paris, 647 p.

[24] Hefny, K., Farid, M.S., Morsi, A., Khater, A.R., El-Ridi, M.R., Khalil, Z.B., Atwia, A. and Attia, D. (1980) Groundwater Studies for the Tenth of Ramadan City. Unpublished Internal Rept., RIGW, MPWWR, El Kanater, Cairo, 54 p.

[25] Cronican, A.E. and Gribb, M.M. (2004) Hydraulic Conductivity Prediction for Sandy Soils. Ground Water, 42, 459-464. 
https://doi.org/10.1111/j.1745-6584.2004.tb02694.x

[26] Odoing, J. (2007) Evaluation of Empirical Formulae for Determination of Hydraulic Conductivity Based on Grain-Size Analysis. Journal of American Science, 3, 54-60.

[27] Gheorhge, A. (1979) Processing and Synthesis of Hydrogeological Data. Abacus Press, London.

[28] Khalaf, S. and Gad, M.I. (2015) Modeling of Contaminant Transport in 10th of Ramadan City Area, East Delta, Egypt. International Journal of Water Resources and Environmental Engineering, 7, 139-152. https://doi.org/10.5897/IJWREE2014.0616

[29] Gad, M.M. (1995) Hydrogeological Studies for Groundwater Reservoirs, East of the Tenth of Ramadan City and Vicinities. Unpublished M.Sc. Thesis, Ain Shams Univ.

[30] Ismail, H.M.G. (2008) Study the Vulnerability of Groundwater Aquifer for Pollution in Wadi El-Tumilat, Eastern Delta. Unpublished M.Sc. Thesis, Fac. of Sci., Cairo Univ, Cairo.

[31] Anning, D.W. (2003) Assessment of Selected Inorganic Constituents in Streams in the Central Arizona Basins Study Area, Arizona and Northern Mexico, through 1998. USGS, National Water-Quality Assessment Program, Water-Resources Investigations Report 03-4063, 127 p.

[32] EHCW (Egyptian High Committee of Water) (2007) Standards and Specifications of Water for Drinking and Domestic Use. Decision of the Minister of Health and Population No. 458 (2007), Ministry of Health and Population, 10 p. (In Arabic)

[33] APHA (American Public Health Association) (1981) Standard Methods for the Examination of Water and Wastewater. APHA, $1134 \mathrm{p}$.

[34] Winograd, I. and Roberson, F. (1982) Deep Oxygenated Ground Water, Anomaly or Common Occurrence? Science, 21, 1227-1229.

https://doi.org/10.1126/science.216.4551.1227

[35] Krauskopf, K.B. and Bird, D.K. (1995) Introduction to Geochemistry. 3rd Edition, McGraw Hill, New York, 227 p. 